\title{
Late-stage groundmass differentiation as a record of magma stagnation, fragmentation, and rewelding
}

\author{
Mayumi Mujin ${ }^{1}\left[\right.$ : $\cdot$ Michihiko Nakamura ${ }^{1}$
}

Received: 17 October 2019 / Accepted: 20 May 2020 / Published online: 28 May 2020

(C) The Author(s) 2020

\begin{abstract}
In the 2011 eruption of Shinmoedake of the Kirishima volcano group, sub-Plinian eruptions were followed by lava extrusion with intermittent Vulcanian explosions. The interstices of microlites and relatively large nanolites ( $>0.4 \mathrm{~nm}$ width) in the groundmass of pyroclasts ("groundmass interstices") were studied to reveal shallow magmatic processes that lead to different eruption styles. The pumice of the sub-Plinian eruption has the least differentiated groundmass interstices composition. The groundmass interstices of the dense juvenile fragments of the Vulcanian explosions are divided into two groups. The first group is the most differentiated as expected from their lava-like texture, whereas the second group is less differentiated and covers the range of subPlinian pumice. The Vulcanian pumice overlaps the dense juvenile fragments despite their high vesicularity. This seemingly contradictory relationship of composition in the interstitial groundmass indicates the clastogenic lava origin of the lessdifferentiated group of dense juvenile fragments. In contrast, magmas stagnated in the shallow conduit maintained elevated temperature and water content, allowing groundmass interstices to differentiate by microlite growth. These magmas then erupted as pumice in the Vulcanian explosions and were effused as lava that was fragmented by subsequent explosions to be later sampled as a dense juvenile fragment. The groundmass crystallinity increased by 9.1 vol. $\%$ in 5-45 days between the sub-Plinian and Vulcanian eruptions, increasing initial melt and magma viscosity from $10^{6.1-7.4}$ and $10^{7.0-8.3} \mathrm{~Pa}$ s to $10^{6.9-8.4}$ and $10^{8.2-9.7} \mathrm{~Pa}$ $\mathrm{s}$, respectively. This viscosity increase by nanolite crystallization could have facilitated the stress fragmentation of conduit magma, leading to Vulcanian explosions. Post-fragmentation expansion of the sub-Plinian pumice could have been suppressed by this viscosity increase, resulting in their low vesicularity. Late-stage groundmass differentiation can thus control shallow magmatic processes.
\end{abstract}

Keywords Groundmass $\cdot$ Microlite $\cdot$ Nanolite $\cdot$ Vulcanian eruption $\cdot$ Kirishima

\section{Introduction}

Recent petrologic studies on volcanic eruption dynamics have revealed that the explosive/effusive transition is often determined by shallow-level processes including depressurization of conduit magmas (Castro and Gardner 2008), viscosity increase through dehydration-induced crystallization of matrix melt (Clarke et al. 2007; Preece et al. 2016), and rewelding of

Editorial responsibility: S. Self

Mayumi Mujin

mayumi.mujin.a5@tohoku.ac.jp

1 Department of Earth Science, Graduate School of Science, Tohoku University, 6-3, Aramaki-Aza-Aoba, Aobaku, Sendai 980-8578, Japan once-fragmented magmas in a shallow volcanic conduit (Castro et al. 2014; Gardner et al. 2017). The transition of eruption styles in some recent eruptions is recorded in the nanoscale crystallization of groundmass (Mujin and Nakamura 2014; Mujin et al. 2017), which could have affected the explosion behavior through magma viscosity (Di Genova et al. 2017). In these studies, the crystallization of nanolites and ultrananolites was examined by measuring crystal size distribution (CSD) and other crystallographic characters with high-resolution field-emission scanning electron microscopes (FE-SEM) and transmission electron microscopy (TEM) as well as Raman spectroscopy. This suggests that late-stage differentiation of matrix melt records such nanoscale crystallization because the growth of pre-existing crystals (i.e., phenocrysts and microlites) should have occurred along with nucleation and growth of new crystals. 
The nanolite was first differentiated from the microlite based on the kink and gap in CSDs (Sharp et al. 1996; Mujin and Nakamura 2014). Mujin et al. (2017) later redefined the nanolite as crystals with $30 \mathrm{~nm}$ to $1 \mu \mathrm{m}$ width, and the ultrananolite as those $<30 \mathrm{~nm}$ in diameter, following the size-based definitions of microlite $(1-30 \mu \mathrm{m})$ and microphenocryst (30-100 $\mu \mathrm{m})$ (Cashman 1992). The crystallization conditions of microlites have been investigated through decompression experiments that simulate magma ascent from a magma chamber. In these experiments, the final pressure was investigated as low as $5 \mathrm{MPa}$ (e.g., Hammer and Rutherford 2002; Brugger and Hammer 2010; Martel 2012). Conversely, crystallization conditions of nanolites and ultrananolites have not been studied experimentally. Schlinger et al. (1986) investigated the Fe-oxide ultrananolites in a welded tuff during cooling, and Sharp et al. (1996) described the pyroxene nanolites in obsidian formed after the emplacement. Mujin et al. (2017) revealed that nanolites of plagioclase, pyroxene, and Fe oxide in the quenched andesitic pumice and dense juvenile fragments of the 2011 eruption of Shinmoedake formed syn-eruptively in the shallow conduit during magma ascent. They found that the CSDs of plagioclase and the number density of magnetite in the submicrometer scale recorded the transition of eruption styles. Namely, the magma fragmentation of the sub-Plinian eruption occurred before the increase of the nucleation rate of plagioclase nanolite, whereas the Vulcanian pumice was formed after that. Rock magnetic and mineralogical characteristics were focused in these studies, whereas chemical differentiation of groundmass resulted from nanoscale crystallization has not been investigated despite its potential to control the eruption dynamics through its effects on magma rheology.

In this study, we performed a comparative petrographic study of various erupted materials from the 2011 eruption of the Shinmoedake, Kirishima volcano group. The 2011 eruption of Shinmoedake began with three sub-Plinian eruptions and was followed by lava extrusion in the crater and intermittent Vulcanian explosions (Miyabuchi et al. 2013; Nakada et al. 2013). In the Vulcanian explosions, dense juvenile fragments (lava fragments) were ejected along with pumice. By considering the order of explosivity and resulting shallow magma residence time, the interstitial groundmass can be differentiated in the order of pumice of sub-Plinian eruptions, pumice of Vulcanian explosions, and dense juvenile fragments derived from Vulcanian explosions. However, a group of dense juvenile fragments exhibits a composition almost identical to that of pumice of the sub-Plinian eruption, i.e., they are less differentiated than the pumice of Vulcanian explosions. Contrastingly, the silica-rich part of the pumice of Vulcanian explosions overlaps with the more silica-rich dense juvenile fragments. This paradoxical compositional relationship is discussed in relation to the shallow-level eruption processes. Furthermore, we estimate the crystallization rate and viscosity increase during this process and discuss their volcanological implications.

\section{Shinmoedake 2011 eruption}

The 2011 eruption of Shinmoedake was the first large magmatic eruption that occurred in the Kirishima volcano group (Fig. 1; Fig 1a is drawn based on Kamada 2014, Japan Meteorological Agency (JMA) 2013, and Japan Coast Guard (JCG) 2014; Fig 1b is modified after Geospatial Information Authority of Japan (GSI) 2020) in 295 years (Imura and Kobayashi 1991). The main phase of eruptive activity was characterized by sub-Plinian eruptions and subsequent lava extrusions with intermittent Vulcanian explosions from January 26 to 31 , followed by frequent Vulcanian explosions
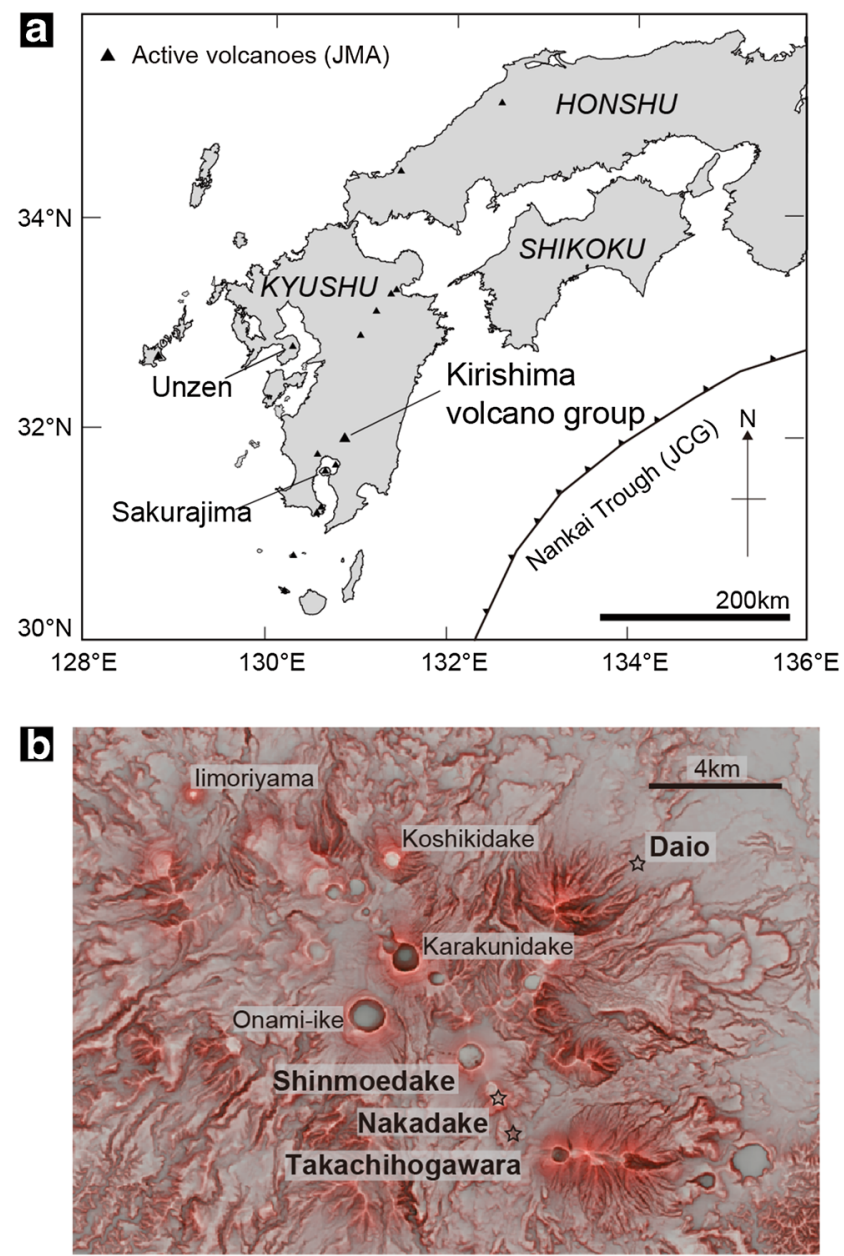

Fig. 1 a Location map of the Kirishima volcano group. Coastlines are drawn using MapMap (version 6.0, Kamada 2014). Active volcano information here was obtained from the National Catalogue of the Active Volcanoes in Japan (Japan Meteorological Agency, JMA 2013), and Nankai Trough location was obtained from a bathymetric chart of Japan Coast Guard (JCG 2014). b Red relief image map of the Kirishima volcano group produced by Asia Air Survey Co., Ltd. (Geospatial Information Authority of Japan website, GSI 2020), with major eruption centers and sampling points of Takachihogawara, Nakadake, and Daio 
from February 1 to March 13 (Miyabuchi et al. 2013; Kozono et al. 2013). No clear precursor before the major eruptions was recorded at the observation stations, suggesting that the erupted magma was stored in a shallow part of an existing conduit before eruption (Ueda et al. 2013).

The eruption sequence was well documented by various geophysical observations. On the evening of January 26 and in the morning and evening of January 27 , three major subPlinian eruptions were detected by weather radar eruption cloud echo measurements (Shimbori et al. 2013). Geodetic and synthetic aperture radar (SAR) observations revealed that the three sub-Plinian eruptions continued for 2.5, 2.5, and 1.75 h, respectively (Kozono et al. 2013). From January 29 to 31, continuous growth of a pancake-shaped mass of lava inside the summit crater was detected by SAR imaging analysis (Ozawa and Kozono 2013). Furthermore, Vulcanian explosions generating infrasound occurred 13 times from 15:41 JST (Japan Standard Time, UTC + 09:00), January 27, to 19:23, March 1 (JMA 2012).

\section{Samples and methods}

\section{Samples}

Samples were collected from three localities: Takachihogawara, 3-km south of the Shinmoedake crater; Daio, 7-km northeast of the Shinmoedake crater; and the summit of Nakadake, 1-km south-southeast of the Shinmoedake crater (Fig. 1b) on July 24, 2011, February 19, 2011, and July 23, 2015, respectively. The pyroclastic fall deposits collected at Takachihogawara include lapilli-sized brown-gray pumice, white pumice, banded pumice with brown-gray and white layers, and dense juvenile fragments $<5 \mathrm{~cm}$ in diameter (Fig. 2a). The sub-Plinian brown-gray and white pumice were collected from a well-sorted pumice fall deposit (layers 2-5 of Nakada et al. 2013). The fine ash of the intensive Vulcanian explosion at 15:41 on January 27 (unit $3 \mathrm{~L}$ of Miyabuchi et al. 2013) was excluded. The Vulcanian brown-gray pumice and dense juvenile fragments were collected from the topmost surface of the pumice deposits of the three sub-Plinian eruption columns (layer 5 of Nakada et al. 2013; unit 3 U of Miyabuchi et al. 2013). The explosion date of the Vulcanian samples obtained at Takachihogawara has not been determined. However, according to the wind direction and eruption cloud height reported in the volcanic activity documents of the JMA (JMA 2011), the most likely date is either February 1, February 11, or March 13, 2011. Two lapilli-sized dense juvenile fragments collected from Daio were provided by Dr. Tajima, NipponKoei Co., Ltd. These samples are eruption products of the Vulcanian explosion on February 14, 2011. At the Nakadake summit, we collected fragments of volcanic blocks $\sim 30 \mathrm{~cm}$ in diameter (Fig. 2b), which were scattered on the surface of the pumice fall deposit (Fig. 2c). Relatively larger blocks formed impact craters (Fig. 2d). Dense and angular blocks with glassy smooth luster surfaces were abundant. These volcanic blocks did not show the characteristic structures of a breadcrust bomb. They are assumed to have been derived from a degassed part of the late-stage crater-filling lava.

\section{Petrographic observations}

The pumice clasts and dense juvenile fragments were rinsed with distilled water ultrasonically for $5 \mathrm{~min}$, impregnated with epoxy resin, and cut and mirror polished with alumina powder. The phenocryst assemblage of the samples is plagioclase, hypersthene, augite, magnetite, and ilmenite, with a trace amount of olivine except for the white pumice. The microlite assemblage of the brown-gray pumice is pyroxenes (mainly augite and hypersthene), plagioclase, and $\mathrm{Fe}-\mathrm{Ti}$ oxide. Pyroxene and plagioclase are the dominant phase of crystals with widths $>5 \mu \mathrm{m}$, and $\mathrm{Fe}-\mathrm{Ti}$ oxide is subordinate. Subhedral to anhedral olivine crystals $\sim 20-30 \mu \mathrm{m}$ in width are occasionally found with occasional pyroxene reaction
Fig. 2 a Dense juvenile fragments collected at Takachihogawara. b Fragments of volcanic blocks at Nakadake summit. c Ground surface of the Nakadake summit. Cross section of the surface deposits can be seen in the front gully. Volcanic blocks dot the surface of the pumice fall deposit. d An impact crater on the Nakadake summit formed by a large volcanic block. Scale bar, 1 $\mathrm{m}$
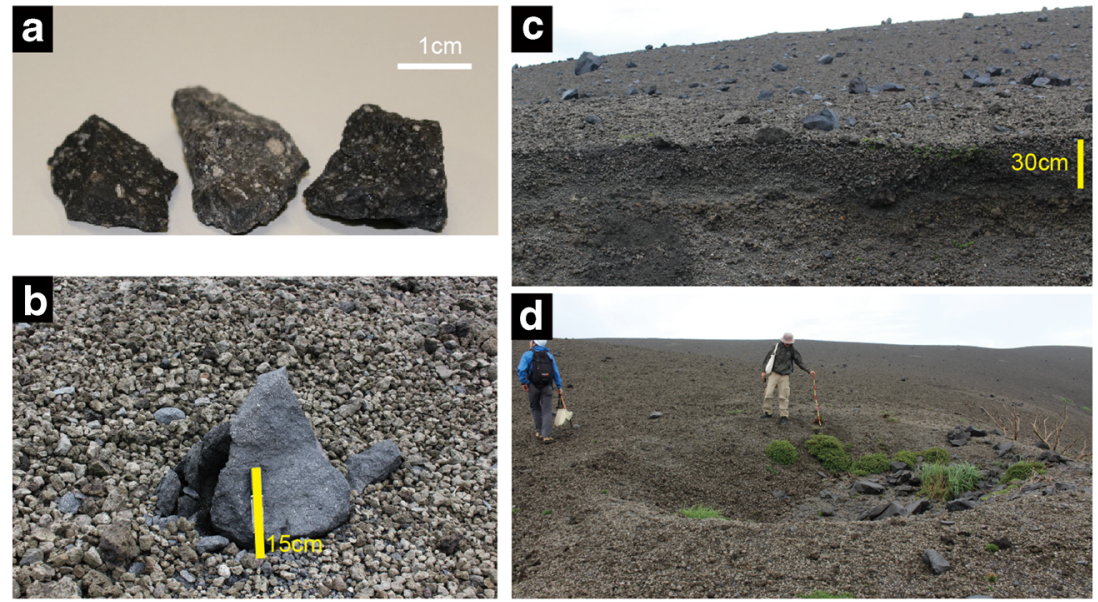
rims. White pumice is almost microlite free, although microlite-sized hypersthene crystals are occasionally found.

Mujin and Nakamura (2014) investigated six clasts of brown-gray pumice from the sub-Plinian eruptions, and five brown-gray pumice clasts and three lapilli-sized dense juvenile fragments from the Vulcanian explosions. Their research found that transitions in eruption styles of the 2011 activity were recorded in the number density of groundmass crystals with $0.4-5.2 \mu \mathrm{m}$ in width. In the present study, we present chemical compositions of groundmass interstices between crystals larger than $\sim 0.4 \mu \mathrm{m}$ in width that reflect the crystallization of microlites and nanolites larger than $\sim 0.4 \mu \mathrm{m}$ in width. We further investigated two clasts of white pumice derived from the sub-Plinian eruptions, and four lapilli-sized dense juvenile fragments and three fragments of volcanic blocks from the Vulcanian explosions. From one of the volcanic block fragments, two polished thin sections were made in an orthogonal direction with each other to check microstructural heterogeneity.

\section{Compositional analyses}

We obtained backscattered electron (BSE) images of the polished sections of the samples using scanning electron microscopy with a tungsten filament (W-SEM; S-3400N, Hitachi High-Technologies) at an acceleration voltage of 15 $\mathrm{keV}$. For higher magnification observations, we used an inlens-type high-resolution field-emission (FE)-SEM instrument (Hitachi High-Technologies S-5500) at acceleration voltages of $2-15 \mathrm{keV}$.

Quantitative analyses of chemical compositions were performed using energy dispersive spectroscopic electron probe microanalyzers (EDS-EPMA; Oxford INCA-Xact attached to the W-SEM) at an acceleration voltage of $15 \mathrm{keV}$ and a beam current of $1 \mathrm{nA}$ using an XPP matrix correction method. This system allows absolute value quantification by performing the calibration using cobalt (Co) metal at each measurement. The calibrated parameters include the probe current based on the relative counting rate of $\mathrm{Co} \mathrm{K} \alpha \mathrm{X}$-ray to that for the standard profile, the energy resolution though the half-value width used for the filter processing of unknown measurement spectra, and the energy of characteristic X-ray through gain adjustment. In this study, the Co calibration was performed every $2 \mathrm{~h}$. The fluctuation of the total values in weight, which was mainly as a result of the probe current fluctuation, is within $5 \%$. The analytical results were then normalized to $100 \%$. The precision $(2 \sigma)$ of the EDS analyses obtained by 22 repeated measurements of a standard sample of natural wollastonite is $0.19 \%$ for $\mathrm{SiO}_{2}$ (52.89\%), 0.17 for $\mathrm{CaO}$ (46.65), and 0.13 for $\mathrm{FeO}$ (0.46). Those for natural orthoclase obtained by 10 measurements are 0.18 for $\mathrm{SiO}_{2}$ (65.23), 0.14 for $\mathrm{Al}_{2} \mathrm{O}_{3}$ (18.37), 0.09 for $\mathrm{Na}_{2} \mathrm{O}$ (1.26), and 0.24 for $\mathrm{K}_{2} \mathrm{O}$ (15.14). Irrespective of the concentration and atomic number, the precision $(2 \sigma)$ is primarily in the range of $0.1-0.2 \mathrm{wt} \%$. The standard deviation $(2 \sigma)$ of the number of cations per 24 oxygen is $0.02-0.03$ for wollastonite and 0.01-0.04 for the orthoclase. Based on these values, we estimate the precisions of $\mathrm{Wo}\left(=\mathrm{Ca} /\left(\mathrm{Mg}+\mathrm{Fe}^{2+}+\right.\right.$ $\mathrm{Ca})$ in $\mathrm{mol} \%)$, En $\left(=\mathrm{Mg} /\left(\mathrm{Mg}+\mathrm{Fe}^{2+}+\mathrm{Ca}\right)\right)$, and $\mathrm{Fs}\left(=\mathrm{Fe}^{2+} /\right.$ $\left.\left(\mathrm{Mg}+\mathrm{Fe}^{2+}+\mathrm{Ca}\right)\right)$ components are within $0.02-0.30 \mathrm{~mol} \%$ in the compositional range of this study (Table 3 ).

We analyzed the compositions of bulk groundmass excluding phenocrysts by scanning rectangular areas of $254 \times 190$ $\mu \mathrm{m}^{2}$ (500-fold magnification) or $127 \times 95 \mu^{2}$ (1000-fold magnification) and groundmass interstices excluding crystals larger than $0.4 \mu \mathrm{m}$ in width or diameter, i.e., microlites and relatively large nanolites, by a focused electron beam ("point analyses"). Judging from the hole size made after the point analyses, the practical beam diameter is approximately 600 $\mathrm{nm}$. The analyses were determined by BSE images of 1000 1500 -fold magnifications. We excluded the diffusive boundary layer around the phenocryst and microlite crystal surfaces from the analysis area, but perfect exclusion was not possible for the Vulcanian pumice and dense juvenile fragments because of their high microlite crystallinity.

The microlite compositions were also analyzed to calculate the chemical differentiation of the melt. The minimum size of the analyzed microlites was $5 \mu \mathrm{m}$ in width or diameter because the approximate maximum value of the depth of the $\mathrm{X}$ ray excitation region at $15-\mathrm{keV}$ acceleration voltage among those for the major elements ( $\mathrm{Si}, \mathrm{Ti}, \mathrm{Al}, \mathrm{Fe}, \mathrm{Mg}$, and $\mathrm{Ca}$ ) was $3.78 \mu \mathrm{m}$ for $\mathrm{Mg}$ according to Castaing's equation (Castaing 1960). The counting losses of $\mathrm{Na}$ and $\mathrm{K}$ in the point analysis of groundmass interstices were corrected with calibration against the area scanning results.

\section{Results}

\section{Microstructural heterogeneity}

All volcanic block fragments and five out of seven dense juvenile fragments from Vulcanian explosions preserve a largely homogeneous groundmass under optical microscopy (Fig. 3a). The other two dense fragments and banded pumice have groundmass heterogeneity in color and transparency under plane-polarized light (Figs. 3b and 4a). The origin of these differences in brightness (color) and appearance was further investigated via observation using high-resolution FE-SEM and composition analyses.

The lightest-toned area under the optical microscope was clearly recognized by SEM because of the lower groundmass crystallinity (e.g., lower abundances of microlites, nanolites, and ultrananolites) (Figs. $3 \mathrm{c}$ and $4 \mathrm{~b}$ and e). The mineral phases of the nanolites are plagioclase, pyroxenes, and Fe-Ti oxides and those of ultrananolites are pyroxene and Fe-Ti oxides (Mujin et al. 2017). The higher crystallinity of ultrananolites 
Fig. 3 a and b Optical photomicrographs of the pyroclasts from the Shinmoedake 2011 eruption with open (left) and crossed (right) Nicols: a homogeneous volcanic block; b heterogeneous dense juvenile fragment. c Backscattered electron (BSE) image of heterogeneous dense juvenile fragment. The bottom part has almost no crystals, corresponding to the lightest-toned area under the unpolarized optical micrograph of (b). Pl, plagioclase; Opx, orthopyroxene; Cpx, clinopyroxene; Ol, olivine
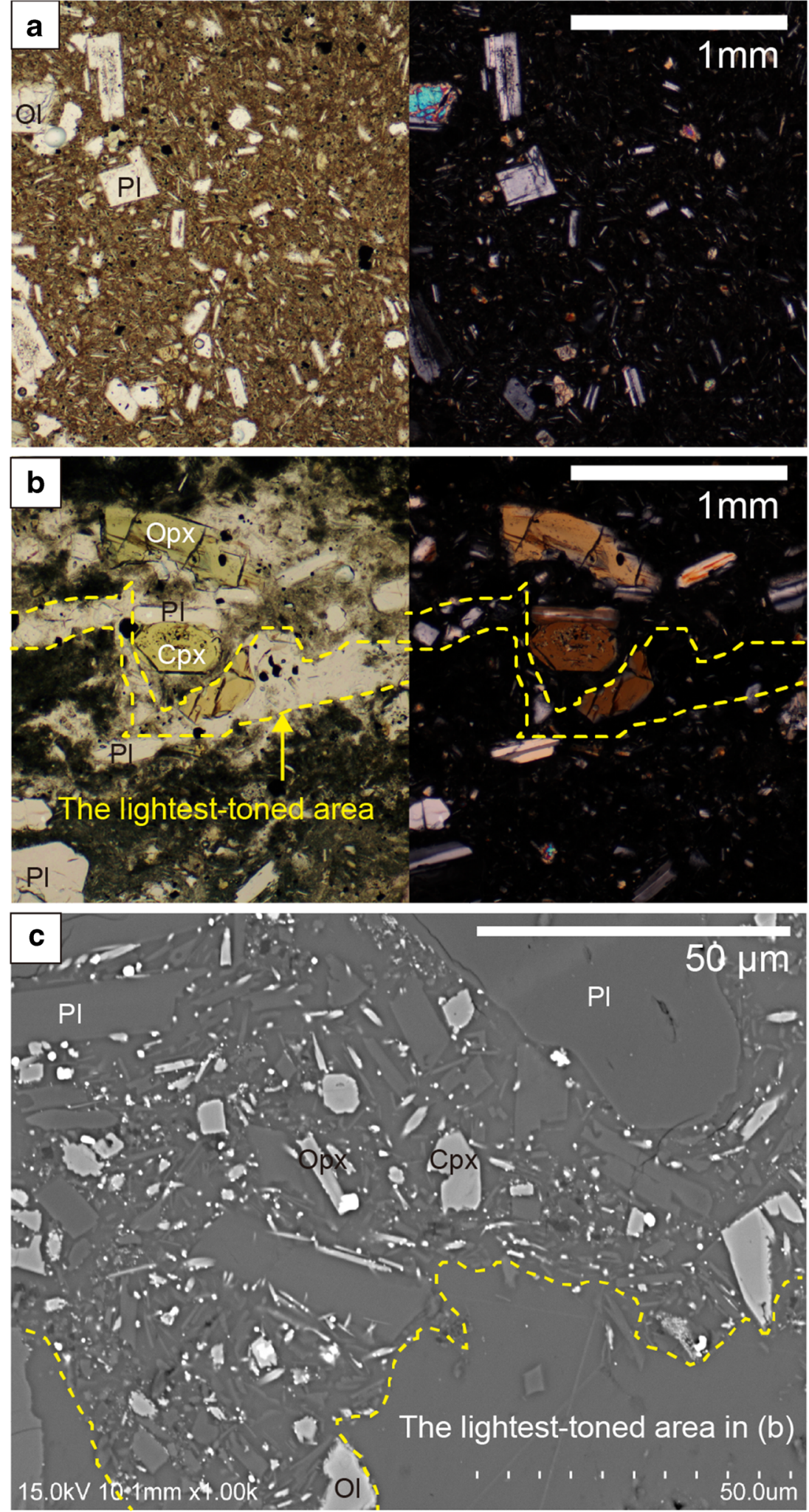

in the darker areas (Fig. 4c) than in the brighter area (Fig. 4d) was recognized via FE-SEM. The positions for interstitial groundmass analyses were selected to cover variation in colors under the optical microscope. Some analytical areas for bulk groundmass composition were selected to include heterogeneity in color.

Although volcanic block fragments have no significant heterogeneity in groundmass under the optical microscope, 
Fig. 4 Optical photomicrograph (open Nicol, (a)) and

backscattered electron (BSE) images $(\mathbf{b}-\mathbf{e})$ of the dense juvenile fragment. The lightest-toned area in a has the lowest crystallinity of groundmass minerals as shown in b and e. Chemical compositions of groundmass interstices indicated by $\mathbf{c}$ and $\mathbf{d}$ belong to group 1, whereas those of $\mathbf{e}$ correspond to white pumice. The groundmass interstice color difference within group 1 under the optical microscope may be attributed to the different degree of light scattering by ultrananolites, i.e., the darker area has higher crystallinity. Pl, plagioclase
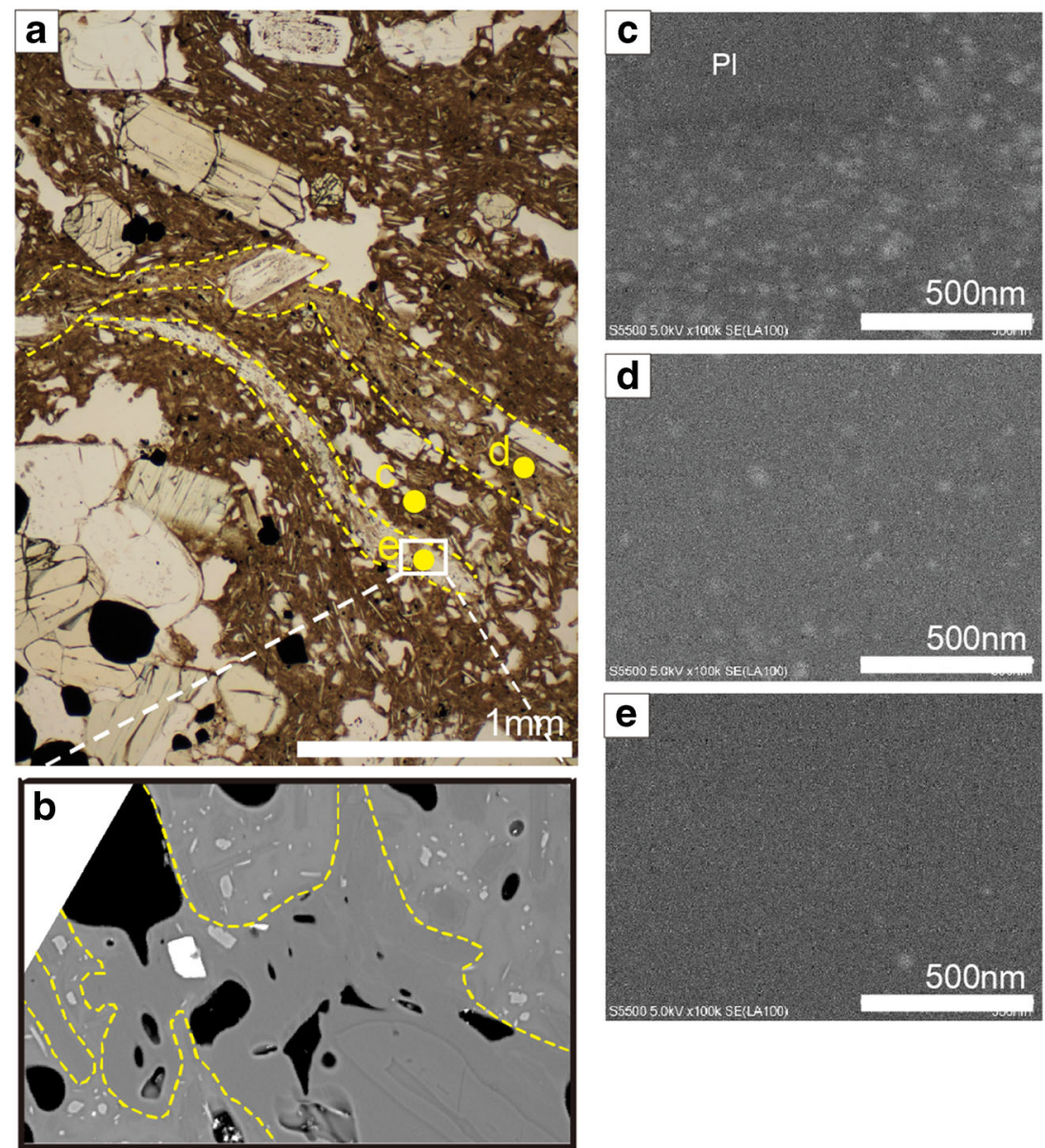

heterogeneous distribution of ultrananolites is occasionally found in the volcanic block fragments when viewed with high magnification SEM (Fig. 5). The heterogeneity tends to include a high abundance of ultrananolites around plagioclase phenocrysts and microlites, and the ultrananolite-free zone near the surface of pyroxene and $\mathrm{Fe}-\mathrm{Ti}$ oxide. This suggests

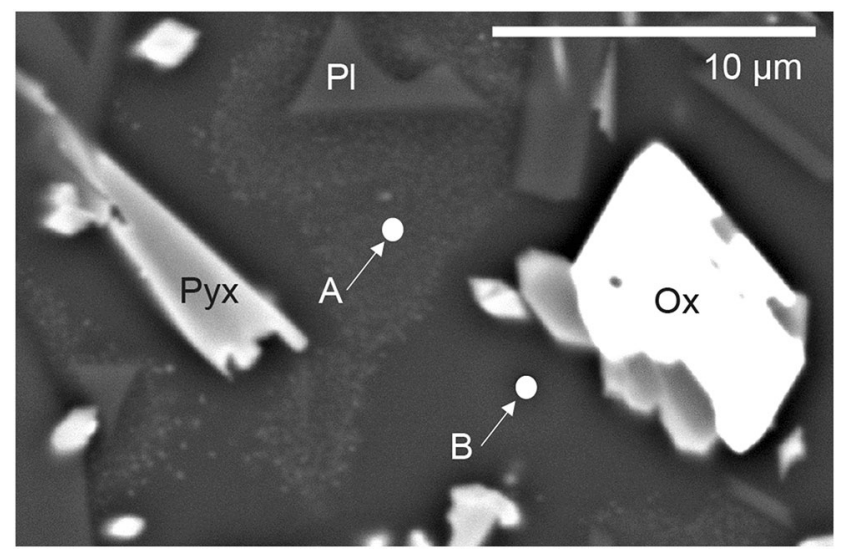

Fig. 5 Backscattered electron (BSE) image of volcanic block groundmass collected at Nakadake summit. Chemical compositions of the groundmass interstices including ultrananolites (point A) are same as that of ultrananolite-free area (point B). Pl, plagioclase; Pyx, pyroxene; Ox, Fe-Ti oxide that the crystallization of ultrananolites started from the diffusive boundary layer of plagioclase, where the mafic component was enriched and then proceeded avoiding the boundary layers of pyroxene and $\mathrm{Fe}-\mathrm{Ti}$ oxides where the mafic component was depleted. High- and low-number density areas for the ultrananolites excluding the boundary layers (points A and $B$ in Fig. 5) have no significant difference in composition (Table 2). This confirms that the X-ray excitation area of the analysis for groundmass interstices is much larger than an ultrananolite, that the assumed differentiation of nanometerscale interstitial melt by ultrananolites crystallization was not detected by the analysis, and that the distribution of ultrananolites is not controlled by chemical heterogeneity of glass except for the boundary layer of crystals.

\section{Groundmass and groundmass crystalline composition}

The bulk groundmass compositions are more differentiated than the whole-rock (bulk rock) compositions (Table 1; Fig. 6). Except for the white pumice whose $\mathrm{SiO}_{2}$ content of bulk rock composition is $62-63 \mathrm{wt} \%$, all the erupted materials were the products of syneruptive magma mixing and found to be chemically similar at $\mathrm{SiO}_{2}=57-58 \mathrm{wt} \%$. The magma of the 


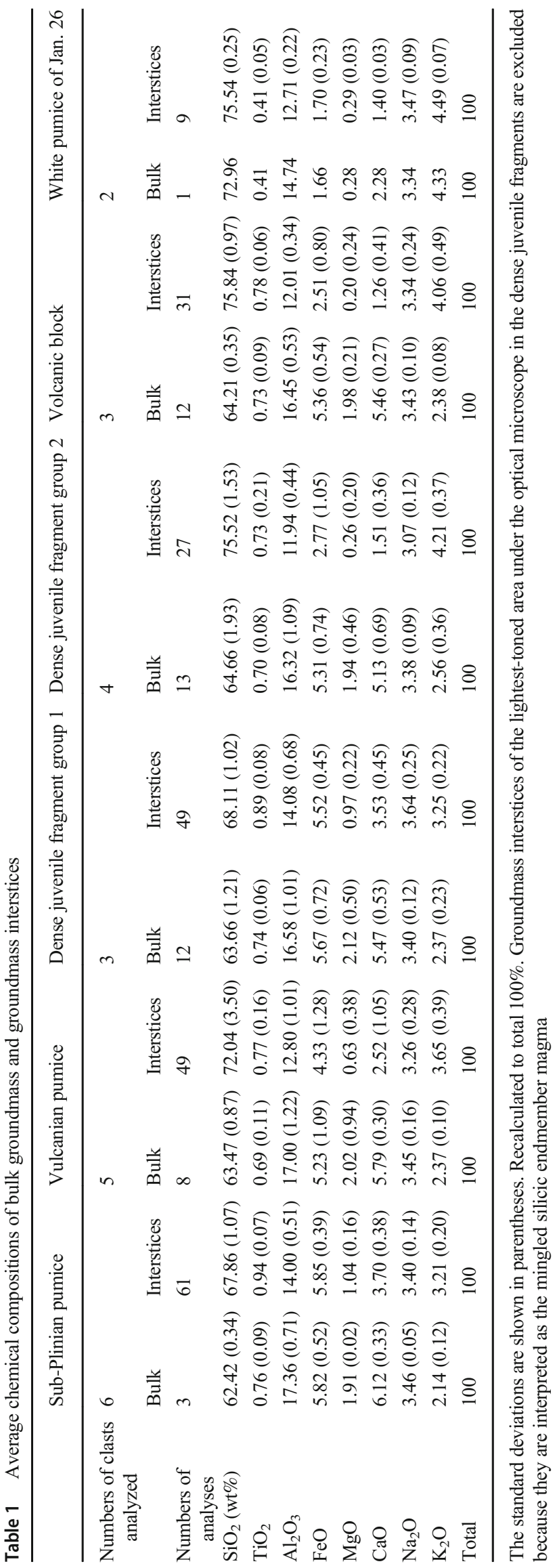

white pumice is assumed to correspond to the dacitic endmember of the magma mixing that formed the majority of the 2011 andesite (Suzuki et al. 2013). The bulk groundmass compositions of the white pumice demonstrated a distinctively silicic composition compared with the brown-gray pumice. The $\mathrm{SiO}_{2}$ contents of the bulk groundmass of brown-gray pumice range from 62 to $65 \mathrm{wt} \%$, whereas that of the white pumice is $73 \mathrm{wt} \%$. The bulk groundmass compositions generally form a trend extending to that of white pumice, although $\mathrm{TiO}_{2}, \mathrm{FeO}$, and $\mathrm{Na}_{2} \mathrm{O}$ are considerably scattered.

To calculate groundmass differentiation, the compositions of microlites with widths $>5 \mu \mathrm{m}$ were analyzed for dense juvenile fragments. In Fig. 7, the compositions of the microlites show large variations, but the measurement area of the bulk groundmass composition is significantly larger than the crystal size and the variation of averaged mineral compositions in the analyzed area is small. The $\mathrm{K}_{2} \mathrm{O}$ shows a small scattering of the bulk groundmass composition which indicates that the effect of compositional variation of each plagioclase crystal is small. The oxide components whose concentrations in the plagioclase microlites are plotted near the extension of the mixing trend $\left(\mathrm{CaO}\right.$ and $\left.\mathrm{K}_{2} \mathrm{O}\right)$ show small scattering, whereas those that are displaced from the extension show relatively large scattering $\left(\mathrm{TiO}_{2}, \mathrm{Al}_{2} \mathrm{O}_{3}, \mathrm{FeO}\right.$, $\mathrm{MgO}$, and $\mathrm{Na}_{2} \mathrm{O}$ ). This implies that the scattering of the bulk groundmass is caused by uneven proportions of plagioclase microlite in the analyzed area.

The groundmass interstices compositions of the brown-gray pumice and the dense juvenile fragments are divided into two groups: less silicic group 1 with $\mathrm{SiO}_{2}<71 \mathrm{wt} \%$ and silicic group 2 with $\mathrm{SiO}_{2}>71 \mathrm{wt} \%$ (Table 1; Fig. 6). Data of all the brown-gray pumice of the sub-Plinian eruptions are included in group 1, whereas those of the pumice and dense juvenile fragments of the Vulcanian explosions are classified into both groups 1 and 2 depending on the clasts; four out of five pumice clasts and four out of seven dense juvenile fragments comprise group 2 . All the analyzed groundmass interstices of the volcanic block fragments have group 2 composition. There is no clear correlation between the grouping of groundmass interstices and bulk groundmass composition. The lightest-toned area in the groundmass of the dense juvenile fragments under the optical microscope (Fig. 4a (area e) and e) has the compositional ranges of the groundmass interstice that cover the groundmass interstices of the white pumice (Fig. 6, Tables 1 and 2; group 2). In contrast, the brighter and darker areas in the dense juvenile fragment (Fig. 4a (area $\mathrm{d}$ and area c), $\mathrm{d}$, and $\mathrm{c}$, respectively) exhibited no difference in composition (Table 2). This suggests that groundmass heterogeneity in color under plane-polarized light is caused by the ultrananolite crystallinity and not by the composition. 

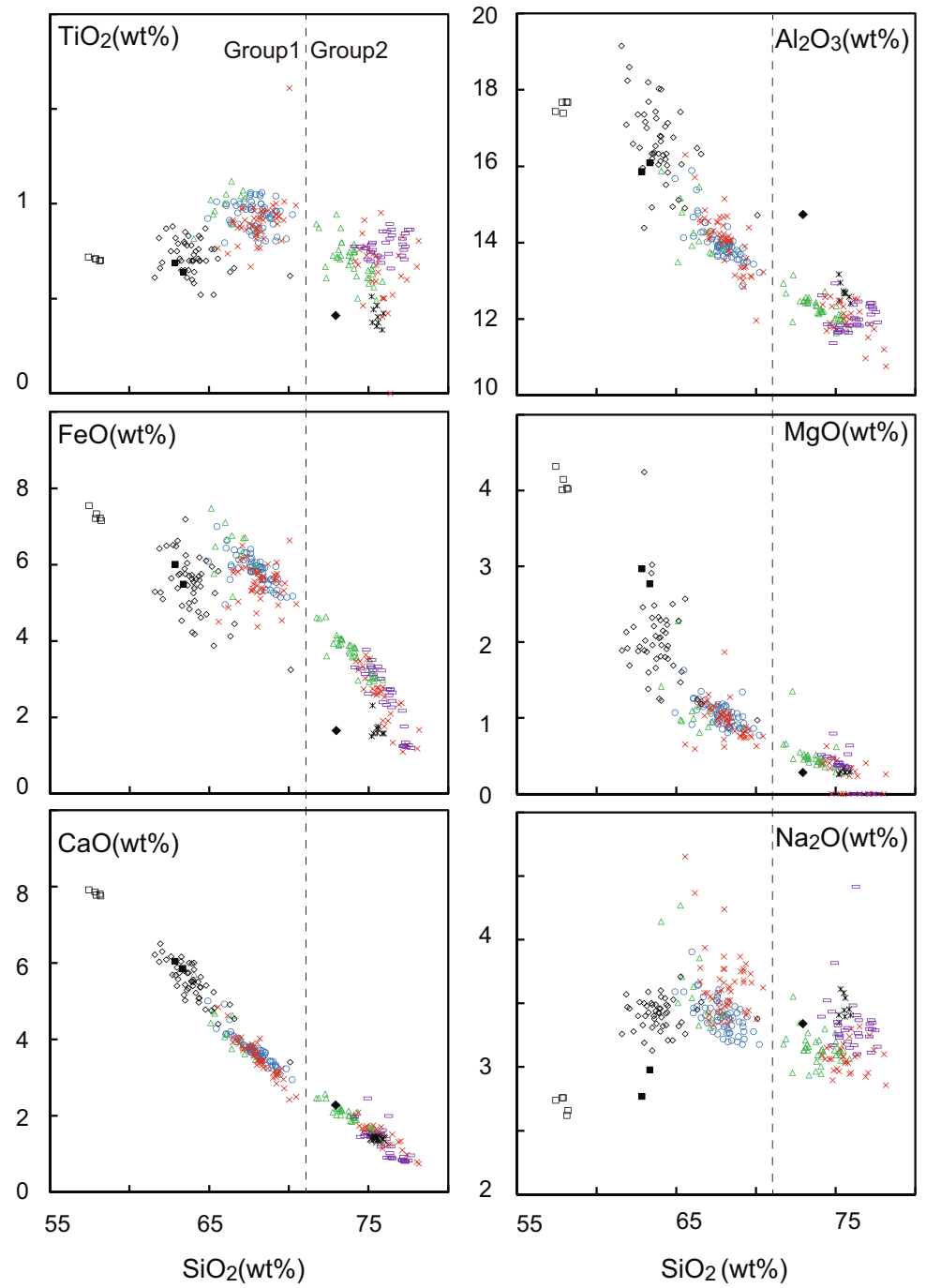

Bulk groundmass

- All samples excluding white pumice

- White pumice

Groundmass interstices

- Sub-Plinian pumice

$\triangle$ Vulcanian pumice

$\times$ Dense juvenile fragment

- Volcanic block

* White pumice

Whole rock (Suzuki et al., 2013)

- Light brown, dark brown, and light gray pumices of sub-Plinian eruption and dense lava of Feb.1

- White pumice of Jan. 26-27
Fig. $6 \mathrm{SiO}_{2}$ variation diagrams of bulk groundmass and groundmass interstice compositions. The bulk groundmass compositions of the samples excluding the white pumice are distributed in a narrow range. Dense juvenile fragments were divided into two groups: relatively less silicic group 1 and silicic group 2. Groundmass interstices of group 1 dense juvenile fragments are similar to those of the sub-Plinian pumice. The pumice of the Vulcanian explosions partly overlaps with the group 2 dense juvenile fragments. Data for whole-rock composition were taken from Suzuki et al. (2013). The precision ( $2 \sigma)$ of EDS analyses (i.e., bulk groundmass and groundmass interstices compositions) is $0.1-0.2 \mathrm{wt} \%$
Pyroxenes and plagioclase are the dominant phase of crystals with widths $>5 \mu \mathrm{m}$, and Fe-Ti oxide is the subordinate phase (Table 3; the ulvöspinel component (Xusp) is calculated according to Stormer 1983). Their average composition $(1 \sigma)$ are as follows: $\mathrm{An} \#(=\mathrm{Ca} /(\mathrm{Ca}+\mathrm{Na})$ in $\mathrm{mol} \%)=66.81(3.31)$ for plagioclase; $\mathrm{Wo}=3.70$ (0.62), $\mathrm{En}=68.55$ (2.27), and $\mathrm{Fs}=$ 27.74 (2.60) for orthopyroxene; Wo $=34.49$ (6.39), $\mathrm{En}=$ 46.82 (4.90), and Fs $=18.69$ (2.15) for clinopyroxene. For Fe-Ti oxides, the average composition of 3 titanomagnetite and 3 titanohematite grains was used. Subhedral to anhedral olivine crystals $\sim 20-30 \mu \mathrm{m}$ in width are sometimes found with occasional pyroxene reaction rims. The mineralogical characterization of the crystals of pyroxene and $\mathrm{Fe}-\mathrm{Ti}$ oxide $<5 \mu \mathrm{m}$ in width in a dense juvenile fragment were presented by Mujin et al. (2017).
Figure 8 shows the core compositions of pyroxene with 5$50 \mu \mathrm{m}$ in width. These are hypersthene, sub-calcic augite, and augite, which are independent of the groundmass interstices composition (i.e., group 1 and group 2 ) in which these pyroxenes are included. These are richer in $\mathrm{Mg}$ compared with pyroxene nanolites and ultrananolites $\sim 20 \mathrm{~nm}-1 \mu \mathrm{m}$ across reported by Mujin et al. (2017). As a result of nucleation and growth occurring in the order of microlites, nanolites, and ultrananolites, this compositional variation with the size is consistent with a crystallization differentiation trend of interstitial melt in the groundmass. The An\# of the core of plagioclase is 55-75. No correlation with the groundmass interstices composition (i.e., group 1 and group 2) is discernible. The chemical data shows that the Fe-Ti oxide minerals $\sim 8-27$ $\mu \mathrm{m}$ in width are titanomagnetite and titanohematite. 

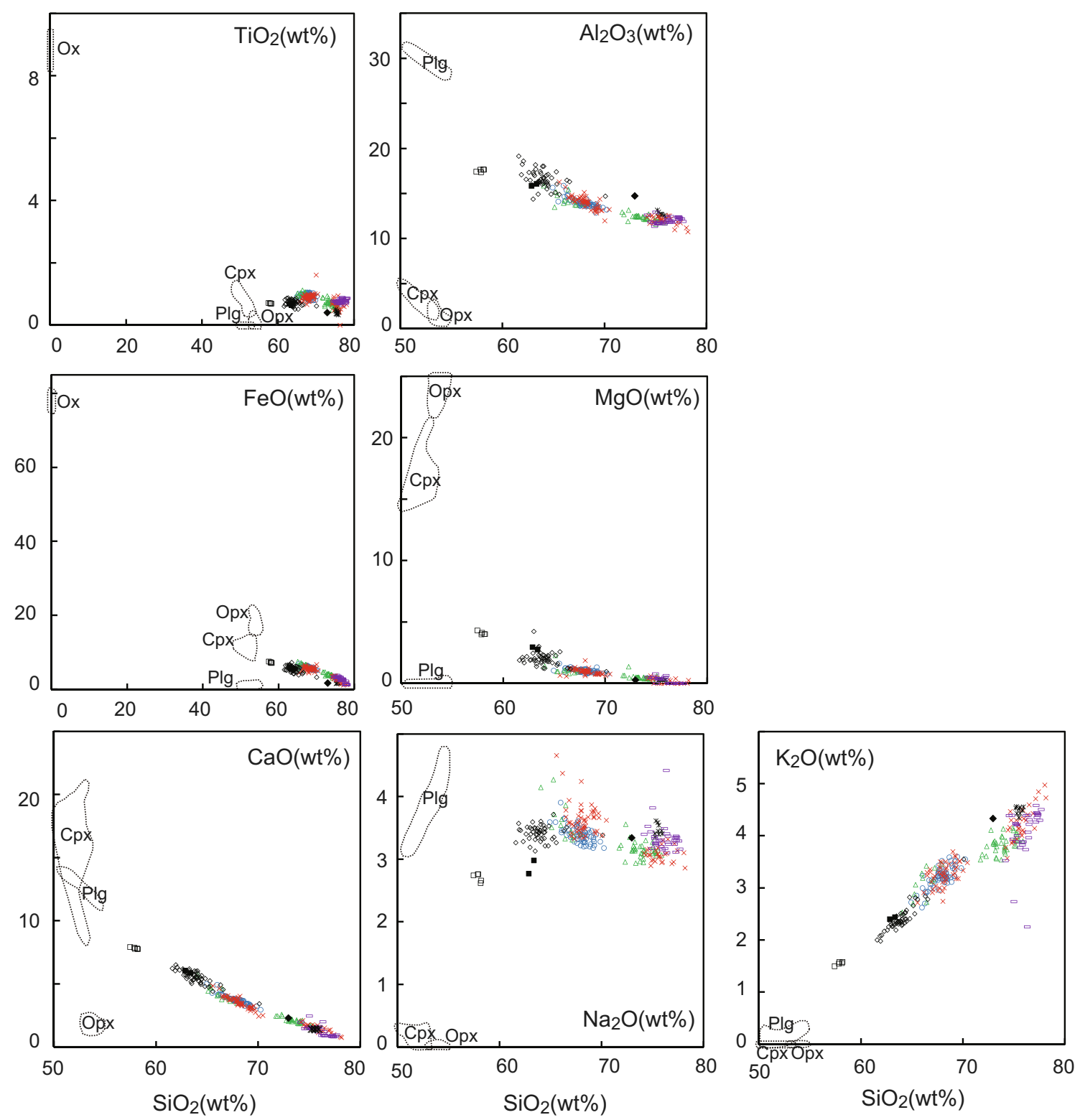

Fig. 7 Microlite compositions of plagioclase (Plg), clinopyroxene (Cpx), orthopyroxene (Opx), and Fe-Ti oxide (Ox) with bulk groundmass and

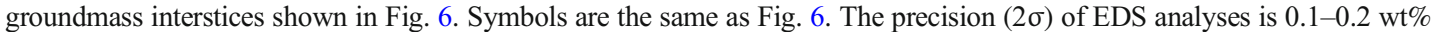

\section{Discussion}

The groundmass texture provides a new opportunity to understand magmatic processes and eruption dynamics in Vulcanian eruptions. Here we first discuss the temporal sequence of groundmass crystallization and other magmatic processes and then calculate the chemical differentiation and its effect on magma viscosity and expansion in the 2011 eruption of the Shinmoedake.

\section{Magma mixing, mingling, and temporal relationship with crystallization}

Suzuki et al. 2013 revealed that all samples except the white pumice are products of magma mixing in the magma chamber. The mixing endmembers are dacitic andesite corresponding to white pumice and basaltic andesite, with a mixing ratio of 3:7 to 4:6. The bulk groundmass compositions generally form a trend extending to that of white pumice, although $\mathrm{TiO}_{2}, \mathrm{FeO}$, and $\mathrm{Na}_{2} \mathrm{O}$ are considerably scattered. The main origin of the observed trend leading to white pumice is considered a variable magma mixing ratio, although some diffusive homogenization is expected to have occurred. This is because brown-gray pumice is formed by incomplete magma mixing (i.e., mingling) between two endmembers.

The lightest-toned area in the groundmass of the dense juvenile fragments under the optical microscope (Fig. 4 a (area e) and e) has the compositional ranges that cover the groundmass interstices of the white pumice (Fig. 6, Tables 1 and 2; 
Table 2 Compositions of groundmass interstices having a different ultrananolite crystallinity

\begin{tabular}{|c|c|c|c|c|c|c|c|c|}
\hline \multirow[t]{2}{*}{ Sample } & \multicolumn{2}{|c|}{ Volcanic block no. 3} & \multicolumn{6}{|c|}{ Dense juvenile fragment no. 2} \\
\hline & & & Group & & Group & & Group & \\
\hline \multirow{2}{*}{$\begin{array}{l}\text { Position } \\
\mathrm{SiO}_{2}(\mathrm{wt} \%)\end{array}$} & \multirow{2}{*}{$\begin{array}{l}\text { Figure } 5 \text { point } A \\
75.87\end{array}$} & \multirow{2}{*}{$\begin{array}{l}\text { Figure } 5 \text { point } B \\
76.90\end{array}$} & \multicolumn{2}{|c|}{ Figure $4 \mathrm{a}$ area $\mathrm{c}$} & \multicolumn{2}{|c|}{ Figure $4 \mathrm{a}$ area $\mathrm{d}$} & \multicolumn{2}{|c|}{ Figure $4 \mathrm{a}$ area $\mathrm{e}$} \\
\hline & & & 66.51 & 66.50 & 66.81 & 67.95 & 75.99 & 75.89 \\
\hline $\mathrm{TiO}_{2}$ & 0.80 & 0.81 & 0.90 & 0.91 & 0.78 & 0.81 & 0.50 & 0.40 \\
\hline $\mathrm{Al}_{2} \mathrm{O}_{3}$ & 12.37 & 12.33 & 14.53 & 14.61 & 14.85 & 14.45 & 12.59 & 12.60 \\
\hline $\mathrm{FeO}$ & 2.34 & 1.25 & 5.79 & 5.87 & 5.04 & 4.73 & 1.77 & 1.91 \\
\hline $\mathrm{MgO}$ & 0.00 & 0.00 & 1.23 & 1.17 & 1.21 & 1.07 & 0.33 & 0.33 \\
\hline $\mathrm{CaO}$ & 1.39 & 0.83 & 4.06 & 3.92 & 4.04 & 3.74 & 1.44 & 1.53 \\
\hline $\mathrm{Na}_{2} \mathrm{O}$ & 3.48 & 3.30 & 3.67 & 3.78 & 3.94 & 3.77 & 3.30 & 3.24 \\
\hline $\mathrm{K}_{2} \mathrm{O}$ & 3.74 & 4.58 & 3.29 & 3.24 & 3.35 & 3.48 & 4.07 & 4.11 \\
\hline Total* & 100 & 100 & 100 & 100 & 100 & 100 & 100 & 100 \\
\hline
\end{tabular}

*Normalized to total $100 \%$

group 2). This shows that the lightest-toned area represents the melt composition of the dacitic endmember left by incomplete magma mixing in the magma chamber or mingling during magma ascent. The crystallinity of the silicic part (i.e., the lightest-toned area) is clearly lower than that of the other part
(Figs. 3 and 4), as expected from the difference in undercooling after the thermal equilibration upon magma mixing (Sparks and Marshall 1986; Frost and Mahood 1987). On the other hand, quenched mafic endmember magma such as mafic enclave has not been reported. The lack of

Table 3 Microlite composition in dense juvenile fragments

\begin{tabular}{|c|c|c|c|c|c|c|c|c|c|c|}
\hline \multirow[b]{2}{*}{ No. of analyzed } & \multirow{2}{*}{$\begin{array}{l}\text { Opx }{ }^{\mathrm{a}} \\
22[4]^{\mathrm{b}}\end{array}$} & \multirow{2}{*}{$\begin{array}{l}\mathrm{Cpx}^{\mathrm{a}} \\
17[4]^{\mathrm{b}}\end{array}$} & \multirow{2}{*}{$\begin{array}{l}\mathrm{Pl}^{\mathrm{a}} \\
39[5]^{\mathrm{b}}\end{array}$} & \multirow{2}{*}{$\begin{array}{l}\mathrm{Ol}^{\mathrm{a}} \\
4[3]^{\mathrm{b}}\end{array}$} & \multicolumn{3}{|c|}{ Ox (titanohematite) } & \multicolumn{3}{|c|}{ Ox (titanomagnetite) } \\
\hline & & & & & & & & & & \\
\hline $\mathrm{SiO}_{2}(\mathrm{wt} \%)$ & $53.82(0.54)$ & $51.59(1.41)$ & $52.08(0.96)$ & $38.70(0.14)$ & & & & & & \\
\hline $\mathrm{TiO}_{2}$ & $0.08(0.14)$ & $0.65(0.31)$ & & & 9.38 & 8.93 & 8.20 & 8.42 & 8.46 & 14.76 \\
\hline $\mathrm{Al}_{2} \mathrm{O}_{3}$ & $1.44(0.65)$ & $3.22(1.42)$ & $30.09(0.78)$ & & 2.57 & 3.66 & 3.71 & 3.91 & 4.12 & 2.19 \\
\hline $\mathrm{FeO}$ & $17.71(1.50)$ & $11.48(1.35)$ & $1.01(0.13)$ & $22.87(0.60)$ & 76.73 & 76.85 & 77.20 & 77.51 & 80.33 & 75.74 \\
\hline $\mathrm{MnO}$ & $0.53(0.11)$ & $0.26(0.18)$ & & $0.20(0.20)$ & & & & 0.56 & 0.42 & \\
\hline $\mathrm{MgO}$ & $24.57(1.01)$ & $16.15(1.92)$ & $0.01(0.04)$ & $38.24(0.64)$ & 2.54 & 2.95 & 2.74 & 2.89 & 0.83 & 1.40 \\
\hline $\mathrm{CaO}$ & $1.86(0.32)$ & $16.50(2.96)$ & $13.12(0.69)$ & & & & & & & \\
\hline $\mathrm{Na}_{2} \mathrm{O}$ & $0.00(0.02)$ & $0.15(0.13)$ & $3.60(0.35)$ & & & & & & & \\
\hline $\mathrm{K}_{2} \mathrm{O}$ & & & $0.09(0.12)$ & & & & & & & \\
\hline $\mathrm{V}_{2} \mathrm{O}_{3}$ & & & & & 0.81 & 0.98 & 1.07 & 1.12 & 0.68 & 0.68 \\
\hline Total & $100^{\mathrm{c}}$ & $100^{\mathrm{c}}$ & $100^{\mathrm{c}}$ & $100^{\mathrm{c}}$ & 92.03 & 93.37 & 92.92 & 94.41 & 94.84 & 94.77 \\
\hline $\mathrm{Wo}^{\mathrm{d}}$ & $3.70(0.62)$ & $34.49(6.39)$ & & & & & & & & \\
\hline$E n^{d}$ & $68.55(2.27)$ & $46.82(4.90)$ & & & & & & & & \\
\hline $\mathrm{Fs}^{\mathrm{d}}$ & $27.74(2.60)$ & $18.69(2.15)$ & & & & & & & & \\
\hline$A n \#^{d}$ & & & $66.81(3.31)$ & & & & & & & \\
\hline $\mathrm{Mg}^{\mathrm{d}}$ & & & & $74.87(0.82)$ & & & & & & \\
\hline Xusp $^{\mathrm{e}}$ & & & & & & & & 0.26 & 0.28 & 0.46 \\
\hline
\end{tabular}

${ }^{a}$ Average compositions and standard deviations are shown in the parentheses. Abbreviations: Opx, orthopyroxene; Cpx, clinopyroxene; Pl, plagioclase; Ol, olivine; Ox, Fe-Ti oxides

${ }^{\mathrm{b}}$ Numbers of analyzed clasts are shown in the brackets

${ }^{\mathrm{c}}$ Recalculated to total $100 \%$

${ }^{\mathrm{d}} \mathrm{Wo}=\mathrm{Ca} /\left(\mathrm{Ca}+\mathrm{Mg}+\mathrm{Fe}^{2+}\right)$ in $\mathrm{mol} \%, \mathrm{En}=\mathrm{Mg} /\left(\mathrm{Ca}+\mathrm{Mg}+\mathrm{Fe}^{2+}\right), \mathrm{Fs}=\mathrm{Fe}^{2+} /\left(\mathrm{Ca}+\mathrm{Mg}+\mathrm{Fe}^{2+}\right), \mathrm{An} \#=\mathrm{Ca} /(\mathrm{Ca}+\mathrm{Na}), \mathrm{Mg} \#=\mathrm{Mg} /\left(\mathrm{Mg}+\mathrm{Fe}{ }^{2+}\right)$

${ }^{\mathrm{e}}$ Calculated according to Stormer (1983) 


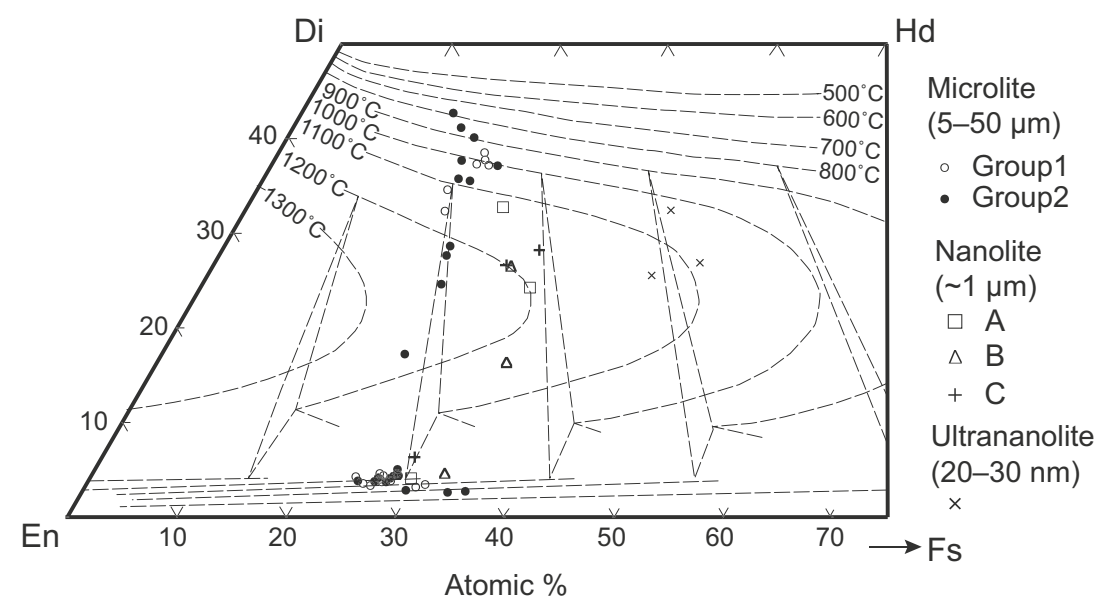

Fig. 8 Pyroxenes composition in the dense juvenile fragments of the Vulcanian explosions. Cores of microlites 5-50 $\mu \mathrm{m}$ in width were analyzed. Microlites in group 1 and group 2 are represented by open and solid circles, respectively. The precision of EDS analyses for microlites of $\mathrm{Wo}\left(=\mathrm{Ca} /\left(\mathrm{Mg}+\mathrm{Fe}^{2+}+\mathrm{Ca}\right)\right.$ in $\left.\mathrm{mol} \%\right), \mathrm{En}(=\mathrm{Mg} /(\mathrm{Mg}+$

correlation between the groups of groundmass interstices and the bulk groundmass composition indicates that the groundmass crystals $<0.4 \mu \mathrm{m}$ were mostly formed after the formation of relatively homogeneous mixed magma and that the difference in the degree of differentiation was formed during magma ascent and emplacement processes. The plagioclase microlite composition has a large compositional variation despite the relatively homogeneous bulk groundmass compositions, suggesting that the plagioclase microlites have crystallized polybarically during the magma decompression.

\section{Calculation of groundmass differentiation}

From the bulk groundmass to the groundmass interstices of the sub-Plinian brown-gray pumice and group 1 dense juvenile fragments, the $\mathrm{TiO}_{2}$ and $\mathrm{K}_{2} \mathrm{O}$ contents increase with increasing $\mathrm{SiO}_{2}$ content, whereas $\mathrm{FeO}$ and $\mathrm{Na}_{2} \mathrm{O}$ contents remain almost constant and $\mathrm{Al}_{2} \mathrm{O}_{3}, \mathrm{MgO}$, and $\mathrm{CaO}$ contents decrease. Among the groundmass interstices, the contents of $\mathrm{K}_{2} \mathrm{O}$ increase, whereas $\mathrm{TiO}_{2}, \mathrm{FeO}, \mathrm{Al}_{2} \mathrm{O}_{3}, \mathrm{MgO}, \mathrm{CaO}$, and $\mathrm{Na}_{2} \mathrm{O}$ contents decrease with increasing $\mathrm{SiO}_{2}$ (Fig. 6). These trends can be formed by the predominant crystallization of plagioclase and pyroxene microlites and relatively large nanolites ( $>0.4 \mu \mathrm{m}$ in width) in the earlier stage of groundmass crystallization, followed by enhanced crystallization of $\mathrm{Fe}-\mathrm{Ti}$ oxide. This may be caused by the later stage magma oxidation near the surface. The composition of pyroxenes with $\sim 5-50 \mu \mathrm{m}$ in width (Fig. 8) and plagioclase with $\sim 5-30 \mu \mathrm{m}$ in width are independent of the groundmass interstices compositions (i.e., group 1 and group 2), which indicates that the plagioclase and pyroxene microlites larger than $5 \mu \mathrm{m}$ should have crystallized in the conduit before the groundmass interstices were differentiated to various degrees depending on the eruption styles (Mujin and Nakamura 2014).
$\left.\left.\mathrm{Fe}^{2+}+\mathrm{Ca}\right)\right)$, and $\mathrm{Fs}\left(=\mathrm{Fe}^{2+} /\left(\mathrm{Mg}+\mathrm{Fe}^{2+}+\mathrm{Ca}\right)\right)$ are within $0.02-0.30$ mol\%. The compositions of nanolite $\sim 1 \mu \mathrm{m}$ in width (square, triangle, and cross) and ultrananolite $\sim 20-30 \mathrm{~nm}$ in diameter (x mark) are from Mujin et al. (2017). The isopleths represent equilibrium pyroxene compositions from Lindsley (1983).

To determine the phase and amount of fractionated minerals, we first obtained the weight proportions of subtracted phases using least squares to derive the groundmass interstice of the sub-Plinian pumice and group 1 dense juvenile fragments from the bulk groundmass. The mass balance of an $n$ component system can be expressed as the following equations assuming a one-step (batch) fractionation:

$\left(\begin{array}{c}X_{1} \\ X_{2} \\ \vdots \\ X_{n}\end{array}\right)=\left(\begin{array}{ccccc}x_{11} & x_{21} & x_{31} & x_{41} & x_{51} \\ x_{12} & x_{22} & x_{32} & x_{42} & x_{52} \\ \vdots & \vdots & \vdots & \vdots & \vdots \\ x_{1 n} & x_{2 n} & x_{3 n} & x_{4 n} & x_{5 n}\end{array}\right)\left(\begin{array}{c}a_{1} \\ a_{2} \\ \vdots \\ a_{5}\end{array}\right)$

and

$a_{5}=\left(1-a_{1}-a_{2}-a_{3}-a_{4}\right)$

where $a_{1}-a_{5}$ are modal compositions of the constituent phases, i.e., plagioclase, clinopyroxene, orthopyroxene, FeTi oxide, and groundmass interstices; $X_{1}-X_{\mathrm{n}}$ are weight percentages of the oxide components of bulk groundmass; and $x_{11}-x_{5 n}$, those of the groundmass minerals and interstices. For this simultaneous equation, the $a_{1}-a_{5}$ were determined so that the SR value of the following equation was minimized.

$\mathrm{SR}=\sum_{i=1}^{n}\left(X_{i}-a_{1} x_{1 i}-a_{2} x_{2 i}-\cdots-a_{5} x_{5 i}\right)^{2}$

In the calculations, we used the average contents of $\mathrm{SiO}_{2}$, $\mathrm{TiO}_{2}, \mathrm{Al}_{2} \mathrm{O}_{3}, \mathrm{FeO}, \mathrm{MgO}, \mathrm{CaO}, \mathrm{Na}_{2} \mathrm{O}$, and $\mathrm{K}_{2} \mathrm{O}$ of the bulk groundmass, groundmass interstices (Table 1), and crystals > $5 \mu \mathrm{m}$ in width as listed in Table 3 .

The calculation results are as follows: orthopyroxene, 5.1 and $4.7 \%$ for sub-Plinian pumice and group 1 dense juvenile fragments, respectively; clinopyroxene, -0.2 and $0.8 \%$; 
plagioclase, 20.2 and $20.0 \%$; and Fe-Ti oxide, 0.0 and $0.2 \%$, where SR is 0.024 and 0.002 for sub-Plinian pumice and group 1 dense juvenile fragments, respectively. As expected from the mostly overlapping compositions of the sub-Plinian pumice and group 1 dense juvenile fragments, the results of subtraction calculations are mostly the same for these two types of pyroclasts. This calculation shows that the crystallization volume of plagioclase is much larger than that of pyroxene, which is consistent with the phase diagrams of simplified systems at atmospheric pressure (cf. the diopside-anorthite-albite and the orthopyroxene-plagioclase-SiOr (quartz + orthoclase)-magnetite pseudo-ternary systems; Mujin et al. 2017) and the CSD diagram (Mujin and Nakamura 2014; Mujin et al. 2017). The CSD slope and number density of plagioclase of approximately $>2 \mu \mathrm{m}$ in width are gentler and higher than that of pyroxene, respectively. This indicates that the growth rate and amount of crystals having the effective size for the differentiation of the groundmass interstices were higher for plagioclase than for pyroxene.

We then calculated differentiation from groundmass interstices of sub-Plinian pumice to groundmass interstices of group 2 Vulcanian pumice, group 2 dense juvenile fragments, excluding the lightest-toned area under the optical microscope, and volcanic block. The average contents of $\mathrm{SiO}_{2}$ in wt.\% are $67.86(2.14,2 \sigma)$ for sub-Plinian pumice, 73.94 (2.11) for group 2 Vulcanian pumice, 75.52 (3.05) for group 2 dense juvenile fragments, and 75.84 (1.95) for the volcanic blocks. Because the compositions of group 2 dense juvenile fragments and the volcanic blocks are mostly overlapped, we show the results from sub-Plinian pumice to group 2 Vulcanian pumice and the volcanic blocks. The phases and amount of subtracted minerals are orthopyroxene ( 0.9 and $0.4 \%$ ), clinopyroxene (2.5 and 4.4\%), plagioclase (13.6 and $15.7 \%$ ), and $\mathrm{Fe}-\mathrm{Ti}$ oxide (3.0 and $4.0 \%$ ) for group 2 Vulcanian pumice and volcanic blocks, respectively. The SR is 0.240 and 0.136 , respectively. The generally increasing fractionation volume for the erupted materials of group 2 in the order of Vulcanian pumice to volcanic blocks indicate that the residence time of magma in the shallow conduit before quenching was extended in this order. Compared with the subtracted proportions in the earlier stage, i.e., from the bulk groundmass to the groundmass interstices of sub-Plinian pumice, the relative crystallization volume of the mafic phases (i.e., pyroxenes and $\mathrm{Fe}-\mathrm{Ti}$ oxide) to plagioclase increases. This is explained by assuming that the earlier extensive crystallization of plagioclase resulted in depletion of the plagioclase component in the melt and an increase in $\Delta T$ for pyroxene and Fe-Ti oxide (see Mujin et al. 2017 for a review of the $\mathrm{Di}-\mathrm{An}-\mathrm{Ab}$ system). The increase of Fe-Ti oxide may also reflect the increase in oxygen fugacity in late-stage crystallization.

\section{Shallow magma ascent processes constrained from the groundmass differentiation}

The group 1 groundmass interstices of the dense juvenile fragments of Vulcanian explosions have similar compositions to the pumice of the sub-Plinian eruption despite their contrasting occurrence. Furthermore, they are less differentiated than the pumice of the Vulcanian explosions that should have been less degassed at the time of fragmentation. This seemingly paradoxical result may be explained by considering the sub-Plinian eruptions, where some proportion of pumice fragments fell back to the crater and were welded to form a part of the crater-filling lava that ultimately became the source of dense juvenile fragments. Compared with the magma stored in the shallow conduit and crater, the once-fragmented and fallen-back pumice should have been degassed more extensively, cooled and oxidized, and thus supercooled. This would have resulted in the nucleation of smaller nanolites and ultrananolites with high number densities, whereas their growth could have been suppressed by slow diffusivity of melt because of dehydration. The insufficient growth of groundmass crystals would hinder the chemical differentiation of groundmass interstices. Contrastingly, magmas stagnated in the shallow conduit were less degassed and supercooled compared to the rewelded magmas; thus, the growth of the pre-existed groundmass crystals such as microlites and relatively larger nanolites $>0.4 \mu \mathrm{m}$ in width should have been easier, enhancing the differentiation of the interstitial melts. These results suggest that a comparative study of the groundmass differentiation of a series of erupted material could be a new approach to uncover the rewelding process.

\section{Rate and timing of crystallization}

To constrain the timing of viscosity increase, we estimated the average rate of the late-stage crystallization. The crystallinity increased from the sub-Plinian pumice erupted on January 2627 (47.1 vol.\%) to the pumice by the Vulcanian explosion occurred either on February 1, 11, or March 13, 2011 (i.e., 5-45 days) (56.2 vol.\%) which is calculated at $9.1 \mathrm{vol} . \%$. This corresponds to the growth rate of $0.20-1.8$ vol. $\%$ day $^{-1}$.

We compared this value with the volumetric crystallization rate obtained by the previous decompression experiment studies, which is a function of the degree of undercooling (difference from the equilibrium crystallinity) as a primary driving force of crystallization, element diffusivity in the melt as a rate-controlling process of crystal nucleation and growth, and the average distance between the nucleus and crystals, i.e., their number density. Hammer (2008) demonstrated that the use of synthetic starting material may be insufficient for the formation of the equilibrium cluster size distribution and fail to reach equilibrium crystallinity at any final pressure along any decompression path; hence, we refer to previous 
studies which used a natural sample (rhyolite, Hammer and Rutherford 2002 and Brugger and Hammer 2010; basaltic andesite, Shea and Hammer 2013 and Szramek et al. 2006). The crystallinity depends on the final pressure and the time kept at the final pressure rather than the decompression rate.

We then chose the experiments with similar final crystallinities. Only two single-step decompression experiments followed by annealing at the final pressure reached the similarly high crystallinity. In the experiment for rhyolite melt (Hammer and Rutherford 2002), crystallinities of 22.0, 58.2, and $65.3 \mathrm{vol} . \%$ were achieved at $10 \mathrm{MPa}$ for 27, 164, and 931 $\mathrm{h}$, respectively. This means the crystallization rates from 27 to $164 \mathrm{~h}$ and from 164 to $931 \mathrm{~h}$ are 6.3 and 0.22 vol. $\%$ day $^{-1}$, respectively. Here we calculated these crystallinities in volume percent from the reported weight proportions assuming the densities $\left(\mathrm{g} / \mathrm{cm}^{3}\right)$ of $2.7,2.65$, and 2.2 for plagioclase, quartz, and glass, respectively (Deer et al. 1992; Best and Christiansen 2001). In the experiment for basaltic andesite melt with melt $\mathrm{SiO}_{2}$ content of 58.78 wt.\% (Shea and Hammer 2013), the crystallinity at $42 \mathrm{MPa}$ increased from 27.8 via 33.1 to 33.7 vol. $\%$ at 12,24 , and $48 \mathrm{~h}$. This gives the crystallization rates of 10.6 and 0.6 vol. $\%$ day $^{-1}$ from 12 to $24 \mathrm{~h}$ and from 24 to $48 \mathrm{~h}$, respectively. At $10 \mathrm{MPa}$ final pressure, crystallinity reached 63.7 vol.\% in $48 \mathrm{~h}$. Therefore, the crystallization rate of the magmas fragmented by the Vulcanian eruption of Shinmoedake is similar to the values near the equilibrium crystallinity irrespective of the crystallization pressure. Assuming that the crystallinity of the basaltic andesite experiments can approximate the Shinmoedake magma, we can estimate that the crystallization of the pumice of both sub-Plinian and Vulcanian eruptions occurred at 10-42 $\mathrm{MPa}$ and was mostly completed within the first few days after emplacement in a shallow conduit.

\section{Viscosity increase as a result of late-stage ground- mass differentiation}

To evaluate the effect of late-stage groundmass differentiation on the eruption dynamics, we estimated magma viscosities at the time of fragmentation. We used the chemical composition, the water content of the interstitial glass, and crystal content in the groundmass of the pumice from the sub-Plinian and Vulcanian eruptions. As the melt compositions, the average composition of groundmass interstice of the pumice was used (Table 1). The meltwater contents of sub-Plinian pumice and Vulcanian pumice were calculated to be $0.35(0.16,2 \sigma$ for $N=$ 3 ) and $0.47(0.24, N=3)$, respectively from the bulk water contents measured by manometric method (Mujin and Nakamura 2014). As the total phenocryst content, the modal composition of $32.3 \mathrm{vol} . \%$ (Sato et al. 2013) was used, and the modal composition of the groundmass crystals $(>0.4 \mu \mathrm{m})$ was recalculated from the mass proportions of the subtracted mineral phases in the differentiation calculation using the following densities $\left(\mathrm{g} / \mathrm{cm}^{3}\right): 3.4$ for pyroxenes; 2.7 , plagioclase; 5.2, Fe-Ti oxide; and 2.35, glass (Deer et al. 1992; Best and Christiansen 2001). The total crystallinity, the sum of the phenocrysts, and groundmass minerals in volume percent were 47.1 and 56.2 vol.\%, respectively, in the sub-Plinian and Vulcanian pumice. The magma temperature after magma mixing was assumed to be $925-980{ }^{\circ} \mathrm{C}$ (Sato et al. 2013; Suzuki et al. 2013).

The melt viscosity corresponding to the groundmass interstices, the residual melt viscosity, was calculated to be $10^{5.6-}$ ${ }^{6.9} \mathrm{~Pa} \mathrm{~s}$ and $10^{6.0-7.6} \mathrm{~Pa}$ s for the sub-Plinian and Vulcanian pumice, respectively, using the method of Giordano et al. (2008). We then calculated the viscosity corresponding to the bulk groundmass, the initial melt viscosity, and total magma viscosity $\left(\eta_{\text {magma }}\right)$ using the residual melt viscosity, the crystal content in the bulk groundmass, and the total crystal content, with the Krieger-Dougherty equation:

$\frac{\eta_{\text {magma containing crystals }}}{\eta_{\text {melt }}}=\left(1-\frac{\varphi}{\varphi_{m}}\right)^{-\varphi_{\mathrm{m}} \varepsilon}$

where $\eta_{\text {magma containing crystal }}$ is initial melt viscosity or magma viscosity, $\varphi$ is the volume fraction of crystals included, $\varphi_{\mathrm{m}}$ is the maximum packing fraction of the crystals, and $\varepsilon$ is the effect of crystal interaction (Krieger and Dougherty 1959). We used the parameters of Sato et al. (2013): $\varphi_{\mathrm{m}}=0.65$ and $\varphi_{\mathrm{m}} \varepsilon=2.5$. The initial melt and magma viscosities were calculated to be $10^{6.1-7.4}$ $\mathrm{Pa} \mathrm{s}$ and $10^{7.0-8.3} \mathrm{~Pa} \mathrm{~s}$ for sub-Plinian pumice, and $10^{6.9-}$ ${ }^{8.4} \mathrm{~Pa} \mathrm{~s}$ and $10^{8.2-9.7} \mathrm{~Pa} \mathrm{~s}$ for Vulcanian pumice, respectively (Fig. 9). For comparison, the viscosity of magma in the magma chamber was estimated from bulk groundmass composition and the phenocryst content $(32.3 \%$; Sato et al. 2013). Assuming a magma temperature of 925 $980{ }^{\circ} \mathrm{C}$ (Sato et al. 2013; Suzuki et al. 2013) and water content in the magma chamber of 4-5 wt\% (Suzuki et al. 2013), the viscosities of the melt and bulk magma in the magma chamber were calculated to be $10^{2.8-3.6} \mathrm{~Pa} \mathrm{~s}$ and $10^{3.6-4.3} \mathrm{~Pa} \mathrm{~s}$, respectively, with $\varphi_{\mathrm{m}}=0.65$ and $\varphi_{\mathrm{m}} \varepsilon=2.5$. The magma viscosity increased by 3.4-4.7 orders of magnitude at the time of magma fragmentation of the subPlinian eruption because of dehydration and crystallization of the microlites and relatively large nanolites and, then, by $1.2-1.4$ orders of magnitude assuming the same temperature and similar water content through the latestage crystallization in the shallow conduit before the Vulcanian explosion.

\section{Effect on fragmentation threshold for Vulcanian explosion}

The magma viscosity increase caused by the late-stage crystallization may carry a significant implication for eruption 

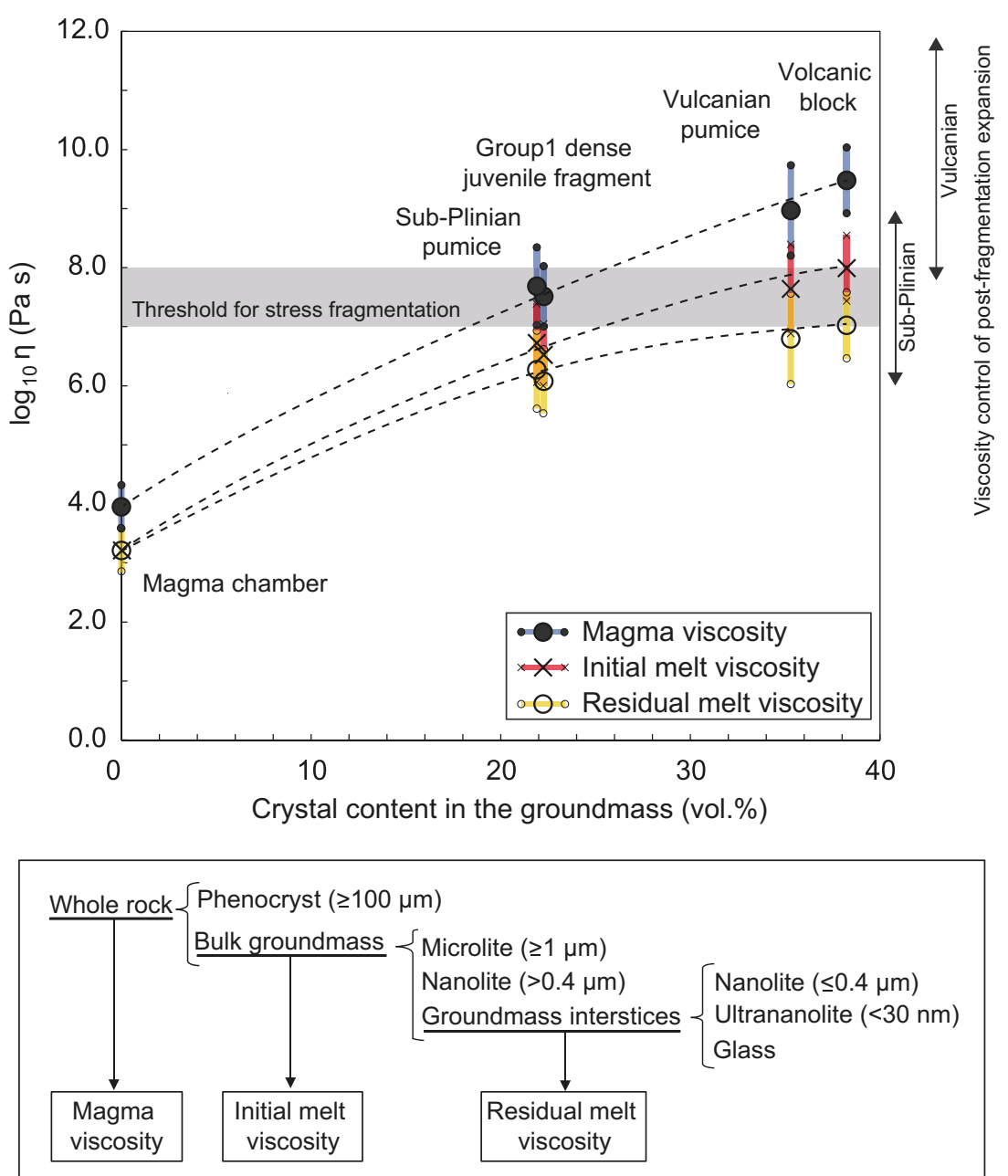

Fig. 9 Relation between bulk, groundmass, and melt viscosities and volume fraction of crystals larger than $0.4 \mu \mathrm{m}$ in groundmass of the sub-Plinian pumice (21.9 vol.\%), group 1 dense juvenile fragment (22.3 vol.\%), Vulcanian pumice (35.3 vol.\%), and volcanic block (38.3 vol.\%). Melt water content is assumed to be $0.19-0.51 \mathrm{wt} \%$ for sub-Plinian pumice, $0.23-0.71 \mathrm{wt} \%$ for Vulcanian pumice, and $0.32-0.56 \mathrm{wt} \%$ for group 1 dense juvenile fragment and volcanic block. Detailed procedure of viscosity calculation is given in the text. The crystal fraction in the groundmass is assumed to be $0 \%$ in the magma chamber which contains
4-5 wt\% water and $32.3 \%$ phenocrysts. Temperature is assumed to be $925-980^{\circ} \mathrm{C}$ for all viscosity calculations. The shaded band at viscosity of $10^{7}-10^{8} \mathrm{~Pa} \mathrm{~s}$ indicates the threshold for stress fragmentation of magmas with tensile strength of $5 \mathrm{MPa}$ and bubble volume fraction of $0.2-0.6$ in a conduit having a radius of $14 \mathrm{~m}$ after Koyaguchi and Mitani (2005). The arrows in the right-hand side represent the viscosity ranges in which postfragmentation bubble expansion is controlled by viscosity calculated after Thomas et al. (1994) dynamics, as high magma viscosity is necessary for Vulcanian explosions to occur through viscoelastic fragmentation upon rapid decompression. Koyaguchi and Mitani (2005) developed a theoretical model for fragmentation of viscous bubbly magmas in shock tubes and obtained the conditions for "stress fragmentation," which is caused when the hoop stress reaches the tensile strength of the melt around the bubbles. The behavior of magmas when a rarefaction wave arrived in a shock tube may be characterized by the dimensionless parameter

$$
\Pi \equiv \frac{r p}{8 \eta_{\text {magma }} a}
$$

where $r$ is conduit radius and $p$ and $a$ are the mean pressure and sound velocity of bubble-bearing magma in the conduit, respectively. Assuming that the tensile strength of magma is 5 $\mathrm{MPa}$, the model predicted that the stress fragmentation criterion is $\Pi<10^{-3}$. If $\Pi>10^{-2}$, the effect of bubble expansion becomes significant. In a natural volcanic system with a conduit radius of $14 \mathrm{~m}$, this corresponds to a magma viscosity higher than $10^{7} \mathrm{~Pa} \mathrm{~s}$ when the bubble volume fraction and pressure drop are 0.2 and $15.5 \mathrm{MPa}$, or 0.6 and $9.5 \mathrm{MPa}$, respectively, and $\eta_{\text {magma }}>10^{8} \mathrm{~Pa}$ s when the bubble volume fraction and pressure drop are 0.6 and $5.5 \mathrm{MPa}$, respectively. It is noteworthy that without the crystallization of nanolites, 
the magma viscosity would not have exceeded this threshold value and a Vulcanian explosion could have failed to occur in the 2011 Shinmoedake eruption.

\section{Effect on the post-fragmentation expansion of pumice}

Another implication of the viscosity increase in this range is the suppression of pumice expansion after the fragmentation. Thomas et al. (1994) examined the effect of magma viscosity on the bubble expansion upon magma decompression as follows:

$p_{e}^{*}=p_{g}^{*}-B \eta_{\text {magma }}^{*} \frac{1}{\varepsilon} \frac{d \varepsilon}{d t^{*}}$

where $p_{\mathrm{g}}{ }^{*}$ is the scaled pressure of the gas inside the bubbles; $p_{\mathrm{e}}{ }^{*}$ is the scaled external pressure; $\eta^{*}$ is the scaled magma viscosity; $\varepsilon$ is the void fraction; and $t^{*}$ is the scaled time. $B$ is a dimensionless number:

$B=\frac{4 \eta_{\text {magma }}}{3 \tau \Delta P}$

where $\Delta P$ is the pressure drop after magma fragmentation and $\tau$ is the time from magma fragmentation to quenching in which bubble expansion is allowed. Here, the surface tension can be ignored when the bubble radius is larger than $10 \mu \mathrm{m}$. In the case of magma expansion after the fragmentation in Plinian eruptions, the decompression rate is a function of the depth of fragmentation and the velocity of the magma fragments in the mist flow $(\sim 5 \mathrm{MPa} / \mathrm{s})$. The results showed that expansion is affected by viscous effects for viscosity values in excess of $10^{6} \mathrm{~Pa} \mathrm{~s}$ and is negligible for $10^{9} \mathrm{~Pa} \mathrm{~s}$ for Plinian eruptions, for which decompression rate of $\sim 5 \mathrm{MPa} / \mathrm{s}$ was assumed. Therefore, the final stage groundmass crystallization is expected to have suppressed the post-fragmentation expansion of nanolite-bearing pumice in the sub-Plinian eruptions of Shinmoedake (Fig. 9). Conversely, the decompression rate for the Vulcanian explosion is estimated to be 1.8-2.9 orders of magnitude smaller than this value $\left(7.0 \times 10^{-3}-7.8 \times 10^{-2}\right.$ $\mathrm{MPa} / \mathrm{s}$; Miwa and Geshi 2012), allowing the postfragmentation expansion for pyroclasts with higher groundmass crystallinity. Given the same fragmentation pressure, viscosity thresholds above which bubble expansion is affected were estimated and become negligible, at $10^{7.8-8.9}$ and $10^{10.8-}$ ${ }^{11.9} \mathrm{~Pa}$ s, respectively (Fig. 9)

\section{Conclusion}

We investigated late-stage groundmass differentiation by microlites and nanolites in the Shinmoedake 2011 eruption, which produced sub-Plinian eruptions and subsequent lava extrusion with intermittent Vulcanian explosions followed by frequent Vulcanian explosions. Although the chemical compositions of bulk groundmass are almost the same for products of these eruptions, the interstices of microlites and relatively large nanolites ( $>0.4 \mathrm{~nm}$ width) in the groundmass show a wide compositional range. The groundmass interstices were differentiated in the order of the pumice of the sub-Plinian eruption and the lessdifferentiated dense juvenile fragments derived from Vulcanian explosions, the pumice of Vulcanian explosions, and the more-differentiated dense juvenile fragments and volcanic blocks derived from Vulcanian explosions. This difference may indicate the following process. Magma fragments in the sub-Plinian activity were vesiculated and quenched mostly as pumice; however, some fell back to the crater and were welded to form a part of the crater-filling lava. The welded lava formed lessdifferentiated dense juvenile fragments, which contain ultrananolites because of large undercooling via degassing, cooling, and oxidation. Further differentiation of groundmass interstices during and after welding was hindered by slow diffusivity in the supercooled melt and glass near the surface of the ground. The groundmass interstices of magma that was stagnated for a longer time in the shallow conduit were differentiated via growth of crystals, and these erupted as pumice, the more-differentiated dense juvenile fragments, and volcanic blocks derived from the Vulcanian explosions. The crystallinity increase in the groundmass of the magma in the crater was estimated to be 9.1 vol.\% in 5-45 days during the Vulcanian explosions, and the magma viscosity increased from the subPlinian to the Vulcanian explosions by $1.2-1.4 \log$ units because of the differentiation of melt and crystallinity increase. This viscosity increase is close to the critical value between viscous expansion and stress fragmentation upon rapid decompression during a Vulcanian explosion. The late-stage groundmass differentiation may thus be used as a clue to elucidate the shallow magmatic processes, such as stagnation and rewelding, operating during Vulcanian explosions.

Acknowledgments The authors thank Dr. Yasuhisa Tajima for providing dense juvenile fragments of the Vulcanian explosion collected at Daio. Reviews by John Stix and an anonymous reviewer greatly improved this manuscript.

Funding information This study was supported by JSPS KAKENHI Grant Numbers JP262753 and JP19K21048 to MM and JP16H06348 to MN, Core Research Cluster of Disaster Science in Tohoku University (Designated National University), and Ministry of Education, Culture, Sports, Science and Technology (MEXT) of Japan, under its Earthquake and Volcano Hazards Observation and Research Program. The tuition fees of MM were supported by a Grant-in-Aid of Tohoku University Institute for Promoting Graduate Degree Programs Division for Interdisciplinary Advanced Research and Education. 
Open Access This article is licensed under a Creative Commons Attribution 4.0 International License, which permits use, sharing, adaptation, distribution and reproduction in any medium or format, as long as you give appropriate credit to the original author(s) and the source, provide a link to the Creative Commons licence, and indicate if changes were made. The images or other third party material in this article are included in the article's Creative Commons licence, unless indicated otherwise in a credit line to the material. If material is not included in the article's Creative Commons licence and your intended use is not permitted by statutory regulation or exceeds the permitted use, you will need to obtain permission directly from the copyright holder. To view a copy of this licence, visit http://creativecommons.org/licenses/by/4.0/.

\section{References}

Best MG, Christiansen EH (2001) Igneous petrology. Blackwell Science, Malden, p p195

Brugger CR, Hammer JE (2010) Crystallization kinetics in continuous decompression experiments: implications for interpreting natural magma ascent processes. J Petrol 51(9):1941-1965

Cashman KV (1992) Groundmass crystallization of Mount St. Helens dacite, 1980-1986: a tool for interpreting shallow magmatic processes. Contrib Mineral Petrol 109:431-449

Castaing R (1960) Electron probe microanalysis. Adv Electron El Phys 13:317-386

Castro JM, Gardner JE (2008) Did magma ascent rate control the explosive-effusive transition at the Inyo volcanic chain, California? Geology 36:279-282

Castro JM, Bindeman IN, Tuffen H, Schipper CI (2014) Explosive origin of silicic lava: textural and $\delta \mathrm{D}-\mathrm{H}_{2} \mathrm{O}$ evidence for pyroclastic degassing during rhyolite effusion. Earth Planet Sci Lett 405:52-61

Clarke AB, Stephens S, Teasdale R, Sparks RSJ, Diller K (2007) Petrologic constraints on the decompression history of magma prior to Vulcanian explosions at the Soufrière Hills volcano, Montserrat. J Volcanol Geotherm Res 161:261-274

Deer WA, Howie, RA, Zussman, J (1992) An introduction to the rockforming minerals 2nd edn, Longman, Harlow, p.155, 166, 170, 177, 431, 457, 558

Di Genova D, Kolzenburg S, Wiesmaier S, Dallanave E, Neuville DR, Hess KU, Dingwell DB (2017) A compositional tipping point governing the mobilization and eruption style of rhyolitic magma. Nature 552:235-238

Frost TP, Mahood GA (1987) Field, chemical, and physical constraints on mafic-felsic magma interaction in the Lamarck Granodiorite, Sierra Nevada, California. GSA Bull 99(2):272-291

Gardner JE, Llewellin EW, Watkins JM, Befus KS (2017) Formation of obsidian pyroclasts by sintering of ash particles in the volcanic conduit. Earth Planet Sci Lett 459:252-263

Geospatial Information Authority of Japan (GSI) (2020) GSI website, https://maps.gsi.go.jp/\#13/31.912415/130.883331/\&base=std\&ls= std $\% 7 C v b m d \_b m \% 7 C r e d \& b l e n d=01 \&$ disp $=111 \& 1 \mathrm{~cd}=$ vbmd bm\&vs $=\mathrm{c} 1 \mathrm{j} 0 \mathrm{~h} 0 \mathrm{k} 010 \mathrm{u} 0 \mathrm{t} 0 \mathrm{z} 0 \mathrm{r} 0 \mathrm{~s} 0 \mathrm{~m} 0 \mathrm{fl}$. Accessed February 2020

Giordano D, Russell JK, Dingwell DB (2008) Viscosity of magmatic liquids: a model. Earth Planet Sci Lett 271:123-134

Hammer JE (2008) Experimental studies of the kinetics and energetics of magma crystallization. Rev Mineral Geochem 69:9-59

Hammer JE, Rutherford MJ (2002) An experimental study of the kinetics of decompression-induced crystallization in silicic melt. J Geophys Res B: Solid Earth 107(B1):ECV-8-1-ECV-8-24

Imura R, Kobayashi T (1991) Eruptions of Shinmoedake Volcano, Kirishima Volcano Group, in the last 300 years. Bull Volcanol Soc Japan 36(2):135-148 (in Japanese with English abstract)
Japan Coast Guard (JCG) (2014) Hydrographic and Oceanographic Department, http://www1.kaiho.mlit.go.jp/jishin/sokuryo/sokuryo. html. Accessed April 2014

Japan Meteorological Agency (JMA) (2011) Volcanic Activity Documents of Kirishimayama volcano: http:/www.data.jma.go.jp/ svd/vois/data/tokyo/STOCK/monthly_v-act_doc/monthly_vact 505.html. Accessed 01 December 2016 (in Japanese)

Japan Meteorological Agency (JMA) (2012) Volcanic activity of Kirishimayama Volcano-February, 2011 - May, 2011. Report of Coordinating Committee for Prediction of Volcanic Eruption 109: 139-167 (in Japanese)

Japan Meteorological Agency (JMA) (2013) National Catalogue of the Active Volcanoes in Japan (The fourth edition, English version), http://www.data.jma.go.jp/svd/vois/data/tokyo/STOCK/souran eng/menu.htm. Accessed 08 October 2016

Kamada T (2014) MapMap ver.6.0, A blank map, http://www5b.biglobe. ne.jp/t-kamada/CBuilder/mapmap.htm. Accessed April 2014

Koyaguchi T, Mitani NK (2005) A theoretical model for fragmentation of viscous bubbly magmas in shock tubes. J Geophys Res 110:B10202

Kozono T, Ueda H, Ozawa T, Koyaguchi T, Fujita E, Tomiya A, Suzuki YJ (2013) Magma discharge variations during the 2011 eruptions of Shinmoe-dake volcano, Japan, revealed by geodetic and satellite observations. Bull Volcanol 75:695-707

Krieger IM, Dougherty TJ (1959) A mechanism for non-Newtonian flow in suspensions of rigid spheres. Trans Soc Rheol 3(1):137-152

Lindsley DH (1983) Pyroxene thermometry. Am Mineral 68:477-493

Martel C (2012) Eruption dynamics inferred from microlite crystallization experiments: application to Plinian and dome-forming eruptions of Mt. Pelée (Martinique, Lesser Antilles). J Petrol 53(4):699-725

Miwa T, Geshi N (2012) Decompression rate of magma at fragmentation: Inference from broken crystals in pumice of vulcanian eruption. J Volcanol Geotherm Res 227:76-84

Miyabuchi Y, Hanada D, Niimi H, Kobayashi T (2013) Stratigraphy, grain-size and component characteristics of the 2011 Shinmoedake eruption deposits, Kirishima Volcano, Japan. J Volcanol Geotherm Res 258:31-46

Mujin M, Nakamura M (2014) A nanolite record of eruption style transion. Geology 42(7):661-614

Mujin M, Nakamura M, Miyake A (2017) Eruption style and crystal size distributions: crystallization of groundmass nanolites in the 2011 Shinmoedake eruption. Am Mineral 102:2367-2380

Nakada S, Nagai M, Kaneko T, Suzuki Y, Maeno F (2013) The outline of the 2011 eruption at Shinmoe-dake (Kirishima), Japan. EPS 65: $475-488$

Ozawa T, Kozono T (2013) Temporal variation of the Shinmoe-dake crater in the 2011 eruption revealed by spaceborne SAR observations. EPS 65:527-537

Preece K, Gertisser R, Barclay J, Charbonnier SJ, Komorowski JC, Herd RA (2016) Transitions between explosive and effusive phases during the cataclysmic 2010 eruption of Merapi volcano, Java, Indonesia. Bull Volcanol 78:54

Sato H, Suzuki-Kamata K, Sato E, Sano K, Wada K, Imura R (2013) Viscosity of andesitic lava and its implications for possible drainback processes in the 2011 eruption of the Shinmoedake volcano, Japan. EPS 65:623-631

Schlinger CM, Smith RM, Veblen DR (1986) Geologic origin of magnetic volcanic glasses in the KBS tuff. Geology 14(11):959-962

Sharp TG, Stevenson RJ, Dingwell DB (1996) Microlites and "nanolites" in rhyolitic glass: microstructural and chemical characterization. Bull Volcanol 57:631-640

Shea T, Hammer JE (2013) Kinetics of cooling-and decompression-induced crystallization in hydrous mafic-intermediate magmas. J Volcanol Geotherm Res 260:127-145

Shimbori T, Sakurai T, Tahara M, Fukui K (2013) Observation of eruption clouds with weather radars and meteorological satellite: a case 
study of the eruption at Shinmoedake volcano in 2011. QJ Seismol 77:139-214

Sparks RSJ, Marshall LA (1986) Thermal and mechanical constraints on mixing between mafic and silicic magmas. J Volcanol Geotherm Res 29(1-4):99-124

Stormer JC Jr (1983) The effects of recalculation on estimates of temperature and oxygen fugacity from analyses of multicomponent irontitanium oxides. Am Mineral 68:586-594

Suzuki Y, Yasuda A, Hokanishi N, Kaneko T, Nakada S, Fujii T (2013) Syneruptive deep magma transfer and shallow magma remobilization during the 2011 eruption of Shinmoe-dake, Japan-constraints from melt inclusions and phase equilibria experiments, J Volcanol Geotherm Res 257:184-204

Szramek L, Gardner JE, Larsen J (2006) Degassing and microlite crystallization of basaltic andesite magma erupting at Arenal Volcano, Costa Rica. J Volcanol Geotherm Res 157:182-201

Thomas N, Jaupart C, Vergniolle S (1994) On the vesicularity of pumice. J Geophys Res B: Solid Earth 99(B8):15633-15644

Ueda H, Kozono T, Fujita E, Kohno Y, Nagai M, Miyagi Y, Tanada T (2013) Crustal deformation associated with the 2011 Shinmoe-dake eruption as observed by tiltmeters and GPS. EPS 65:517-525 